NBER WORKING PAPER SERIES

\title{
SPECIAL PURPOSE VEHICLES AND SECURITIZATION
}

\author{
Gary Gorton \\ Nicholas S. Souleles \\ Working Paper 11190 \\ http://www.nber.org/papers/w11190 \\ NATIONAL BUREAU OF ECONOMIC RESEARCH \\ 1050 Massachusetts Avenue \\ Cambridge, MA 02138 \\ March 2005
}

Thanks to Moody's Investors Service, Sunita Ganapati of Lehman Brothers, and Andrew Silver of Moody's for assistance with data. Thanks to Charles Calomiris, Richard Cantor, Darrell Duffie, Loretta Mester, Mitch Petersen, Jeremy Stein, Peter Tufano, and seminar participants at the Philadelphia Federal Reserve Bank, Moody's Investors Service, and the NBER Conference on the Risks of Financial Institutions for comments and suggestions. Souleles acknowledges financial support from the Rodney L. White Center for Financial Research and a NYSE Fellowship through the Rodney L. White Center. The views expressed herein are those of the author(s) and do not necessarily reflect the views of the National Bureau of Economic Research.

(C) 2005 by Gary Gorton and Nicholas S. Souleles. All rights reserved. Short sections of text, not to exceed two paragraphs, may be quoted without explicit permission provided that full credit, including $@$ notice, is given to the source. 
Special Purpose Vehicles and Securitization

Gary Gorton and Nicholas S. Souleles

NBER Working Paper No. 11190

March 2005

JEL No. G3, G2, E51, K2

\title{
$\underline{\text { ABSTRACT }}$
}

Firms can finance themselves on- or off-balance sheet. Off-balance sheet financing involves transferring assets to "special purpose vehicles" (SPVs), following accounting and regulatory rules that circumscribe relations between the sponsoring firm and the SPVs. SPVs are carefully designed to avoid bankruptcy. If the firm's bankruptcy costs are high, off-balance sheet financing can be advantageous, especially for sponsoring firms that are risky. In a repeated SPV game, firms can "commit" to subsidize or "bail out" their SPVs when the SPV would otherwise not honor its debt commitments. Investors in SPVs know that, despite legal and accounting restrictions to the contrary, SPV sponsors can bail out their SPVs if there is the need. We find evidence consistent with these predictions using data on credit card securitizations.

\author{
Gary Gorton \\ Department of Finance \\ The Wharton School \\ University of Pennsylvania \\ Philadelphia, PA 19104-6367 \\ and NBER \\ gorton@wharton.upenn.edu \\ Nicholas Souleles \\ Finance Department \\ The Wharton School \\ 2300 SH-DH \\ University of Pennsylvania \\ Philadelphia, PA 19104-6367 \\ and NBER \\ souleles@wharton.upenn.edu
}




\section{Introduction}

The use of special purposes vehicles (SPVs) in corporate finance seems to be pervasive. ${ }^{1}$ What is the source of value to organizing corporate activity using SPVs? In this paper we argue that SPVs exist to avoid bankruptcy costs.

By financing the firm in pieces, some on-balance sheet and some off-balance sheet, control rights to the business decisions are separated from the financing decisions. The SPV sponsoring firm maintains control over the business decisions while the financing is done in SPVs that are passive; they cannot make business decisions. Furthermore, the SPVs are not subject to bankruptcy costs because they cannot go bankrupt, as a matter of design. Bankruptcy is a process of transferring control rights over corporate assets. Securitization reduces the amount of assets that are subject to this expensive and lengthy process. We argue that the existence of SPVs depends on implicit contractual arrangements that avoid accounting and regulatory impediments to reducing bankruptcy costs. We develop a model of off-balance sheet financing and test the implications of the model.

An SPV, or a special purpose entity (SPE), is a legal entity created by a firm (known as the sponsor or originator) by transferring assets to the SPV, to carry out some specific purpose, or circumscribed activity, or a series of such transactions. SPVs have no purpose other than the transaction(s) for which they were created, and they can make no substantive decisions; the rules governing them are set down in advance and carefully circumscribe their activities. Indeed, no one works at an SPV and it has no physical location.

The legal form for an SPV may be a limited partnership, a limited liability company, a trust, or a corporation. $^{2}$ Typically, off-balance sheet SPVs have the following characteristics:

- They are thinly capitalized;

- They have no independent management or employees;

\footnotetext{
${ }^{1}$ Below we present the evidence on use of special purpose vehicles in the cases where such data exist. As explained below, these are "qualified" special purpose vehicles. Data on other types of SPVs are not systematically collected.

${ }^{2}$ There are also a number of vehicles that owe their existence to special legislation. These include REMICs, FASITs, RICs, and REITs. In particular, their tax status is subject to specific tax code provisions. See Kramer (2003).
} 
- Their administrative functions are performed by a trustee who follows prespecified rules with regard to the receipt and distribution of cash; there are no other decisions;

- Assets held by the SPV are serviced via a servicing arrangement;

- They are structured so that they cannot become bankrupt, as a practical matter.

In short, SPVs are essentially robot firms that have no employees, make no substantive economic decisions, have no physical location, and cannot go bankrupt. Off-balance sheet financing arrangements can take the form of research and development limited partnerships, leasing transactions, or asset securitizations, to name the most prominent. ${ }^{3}$ And less visible are tax arbitrage-related transactions. In this paper we address the question of why SPVs exist.

The existence of SPVs raises important issues for the theory of the firm: What is a firm and what are its boundaries? Does a "firm" include the SPVs sponsored by the firm? (From an accounting or tax point of view, this is the issue of consolidation.) What is the relationship between a sponsoring firm and its SPV? In what sense does the sponsor "control" the SPV? Are investors indifferent between investing in SPV securities and the sponsor's securities? To make headway on these questions we first theoretically investigate the question of the existence of SPVs. Then we test some implications of the theory using unique data on credit card securitizations.

One argument for why SPVs are used is that sponsors may benefit from a lower cost of capital because sponsors can remove debt from the balance sheet, so balance sheet leverage is reduced. Enron, which created over 3,000 off-balance sheet SPVs, is the leading example of this (see Klee and Butler (2002)). But Enron was able to (apparently fraudulently) keep their off-balance sheet debt from being observed by investors, and so obtained a lower cost of capital. If market participants are aware of the off-balance sheet vehicles, and assuming that the off-balance sheet vehicles truly satisfy the legal and accounting requirements to be off-balance sheet, then it is not immediately obvious how this lowers the cost of capital for the sponsor. In the context of operating leases Lim, Mann, and Mihov (2003) find that bond yields reflect off-balance sheet debt. ${ }^{4}$

\footnotetext{
${ }^{3}$ On research and development limited partnerships see, e.g., Shevlin (1987) and Beatty, Berger, and Magliolo (1995); on leasing see, e.g., Hodge (1996, 1998), and Weidner (2000). Securitization is discussed in detail below.

${ }^{4}$ There are other accounting motivations for setting up off-balance sheet SPVs. Shakespeare $(2001,2003)$ argues, in the context of securitization, that managers use the gains from securitization to meet earnings targets and analysts' earnings forecasts. This is based on the discretionary element of how the "gain on
} 
The key issue concerns why otherwise equivalent debt issued by the SPV is priced or valued differently than on-balance sheet debt by investors. The difference between on- and off-balance sheet debt turns on the question of what is meant by the phrase used above "truly satisfy the ...requirements to be off-balance sheet." In this paper we argue that "off-balance sheet" is not a completely accurate description of what is going on. The difficultly lies in the distinction between formal contracts (which subject to accounting and regulatory rules) and "relational" or "implicit" contracts. Relational contracts are arrangements that circumvent the difficulties of formally contracting (that is, entering into an arrangement that can be enforced by the legal system)..$^{5}$

While there are formal requirements, reviewed below, for determining the relationships between sponsors and their SPVs, including when the SPVs are not consolidated and when the SPVs' debts are off-balance sheet, this is not the whole story. There are other, implicit, contractual relations. The relational contract we focus on concerns sponsors' support of their SPVs in certain states of the world, and investors' reliance on this support even though sponsors are not legally bound to support their SPVs - and in fact under accounting and regulatory rules are not supposed to provide support.

The possibility of this implicit support, "implicit recourse," or "moral recourse" has been noted by regulators, rating agencies, and academic researchers. U.S. bank regulators define "implicit recourse" or "moral recourse" as the "provision of credit support, beyond contractual obligations..." See Office of the Comptroller of the Currency (OCC), et. al (2002, p. 1). The OCC goes on to offer guidance on how bank examiners are to detect this problem. An example of the rating agency view is that of FitchIBCA (1999): "Although not legally required, issuers [sponsors] may feel compelled to support a securitization and absorb credit risk beyond the residual exposure. In effect, there is moral recourse since failure to support the securitization may impair future access to the capital markets" (p. 4). Gorton and Pennacchi $(1989,1995)$ first

sale" is booked. Calomiris and Mason (2004) consider regulatory capital arbitrage as a motivation for securitization, but conclude in favor of the "efficient contracting view," by which they mean that "banks use securitization with recourse to permit them to set capital relative to risk in a manner consistent with market, rather than regulatory, capital requirements and to permit them to overcome problems of asymmetric information... "(p. 26).

${ }^{5}$ On relational contracts in the context of the theory of the firm see Baker, Gibbons, and Murphy (2002) and the references cited therein. 
discussed the issue of implicit recourse in financial markets in the context of the bank loan sales market; they also provide some empirical evidence for its existence.

Nonetheless, there are many unanswered questions. Why are SPVs valuable? Are they valuable to all firms? Why do sponsors offer recourse? How is the implicit arrangement self-enforcing? The details of how the arrangement works and, in particular, how it is a source of value has never been explained. We show that the value of the relational contract, in terms of cost of capital for the sponsor, is related to the details of the legal and accounting structure, which we explain below. To briefly foreshadow the arguments to come, the key point is that SPVs cannot go bankrupt. In the U.S. it is not possible to waive the right to have access to the government's bankruptcy procedure, but it is possible to structure an SPV so that there cannot be "an event of default" which would throw the SPV into bankruptcy. This means that debt issued by the SPV should not include a premium reflecting expected bankruptcy costs, as there never will be any such costs. ${ }^{6}$ So, one benefit to sponsors is that the off-balance sheet debt should be cheaper, ceteris paribus. However, there are potential costs to off-balance sheet debt. One is the fixed cost of setting up the SPV. Another is that there is no tax advantage of off-balance sheet debt to the SPV sponsor. Depending on the structure of the SPV, the interest expense of off-balance sheet debt may not be tax deductible.

After reviewing the institutional detail, which is particularly important for this subject, we then develop these ideas in the context of a simple model. The model analysis unfolds in steps. First, we determine a benchmark corresponding to the value of the stand-alone entity, which issues debt to investors in the capital markets. For concreteness we refer to this firm as a bank. The bank makes an effort choice to create assets of types that are unobservable to the outside investors. Step two considers the situation where the assets can be allocated between on- and off-balance sheet financing, but the allocation of the assets occurs $\underline{\text { before }}$ the quality of individual assets has been determined. From the point of view of investors in the SPV's debt, there is a moral hazard problem in that the bank may not make an effort to create high value assets. The sponsoring bank's decision problem depends on bankruptcy costs, taxes, and other considerations. We provide conditions under which it is optimal for the sponsoring bank to use an SPV.

\footnotetext{
${ }^{6}$ However, as we discuss below, the debt may be repaid early due to early amortization. This is a kind of prepayment risk from the point of view of the investors.
} 
The third step allows the bank to allocate assets $\underline{\text { after }}$ it has determined the qualities of its individual assets. In other words, investors in the debt issued by the SPV face an additional problem. In addition to the moral hazard associated with the effort choice, there is an adverse selection problem with regard to which projects are allocated to the SPV. We call this problem the "strategic adverse selection problem." In this case, investors will not buy the debt of the SPV because they cannot overcome the strategic adverse selection problem. However, we show that if the sponsor can commit to subsidize the SPV in states of the world where the SPV's assets are low quality and the sponsor's on-balance sheet assets are high quality, then the SPV is viable. In particular, if the bank can commit to subsidize the SPV in certain states of the world, then the profitability of the bank is the same as it would be when projects were allocated between the bank and the SPV prior to their realizations, i.e., when there was no strategic adverse selection.

But, how does the commitment happen? Sponsors cannot verifiably commit to state-contingent subsidies. Even if they could verifiably commit to such strategies, legal considerations would make this undesirable; as the courts view such recourse as meaning that the assets were never sold to the SPV in the first place. In this case, the SPV is not bankruptcy remote. As Klee and Butler (2002) write:

The presence of recourse is the most important aspect of risk allocation because it suggests that the parties intended a loan and not a sale. If the parties had intended a sale, then the buyer would have retained the risk of default, not the seller. The greater the recourse the SPV has against the Originator, through for example chargebacks or adjustments to the purchase price, the more the transfer resembles a disguised loan rather than a sale. Courts differ on the weight they attach to the presence of recourse provisions. Some courts view the presence of such a provision as nearly conclusive of the parties' intent to create a security interest, while others view recourse as only one of a number of factors. (p. 52).

This means that, as a practical matter, the recourse must not be explicit, cannot be formalized, and must be subtle and rare.

The final step in the analysis is to show that in a repeated context it is possible to implement a form of commitment. This result is based on the familiar use of trigger strategies (e.g. Friedman (1971), and Green and Porter (1984)), which create an incentive for the sponsor to follow the implicit arrangement. Previous applications of such strategies involve settings of oligopolistic competition, where firms want to collude but cannot observe strategic price or quantity choices of rivals. Intertemporal incentives to collude are maintained via punishment periods triggered by deviations from the implicit collusive arrangements. Our application is quite different. Here 
firms sponsoring SPVs "collude" with the investors in the SPVs by agreeing to the state contingent subsidization of the SPV - recourse that is prohibited by accounting and regulatory rules. In this sense SPVs are a kind of "regulatory arbitrage."

Two empirically testable implications follow from the theoretical analysis. First, because the value in using SPVs derives in large part from avoiding bankruptcy costs, riskier firms should be the ones that engage in off-balance sheet financing. Mills and Newberry (2004) find that riskier firms use more off-balance sheet debt. Also, see Moody's (1997). We first test this proposition.

Second, following Gorton and Pennacchi $(1989,1995)$, implicit recourse implies that investors in the debt of the SPV incorporate expectations about the risk of the sponsor. This is because the sponsor must exist in order to subsidize the SPV in some states of the world. As Moody's (1997) puts it: "Part of the reason for the favorable pricing of the [SPVs'] securities is the perception on the part of many investors that originators (i.e., the 'sponsors' of the securitizations) will voluntarily support - beyond that for which they are contractually obligated - transactions in which asset performance deteriorates significantly in the future. Many originators have, in fact, taken such actions in the past" (p. 40). We also test this proposition.

The empirical work focuses on credit card securitizations. Securitization was chosen because of data availability. Credit cards, in particular, are an interesting asset class because it involves revolving credits that are repeatedly sold into SPVs. Moreover, it is the largest category within non-mortgage securitizations.

The paper proceeds as follows. In Section II we provide some background information on offbalance sheet vehicles generally. Then, in Section III we focus more narrowly on some of the details on how securitization vehicles work specifically. Section IV presents and analyzes a model of off-balance sheet financing. In Section V we explain and review the data sets used in the empirical work. The first hypothesis, concerning the existence of implicit recourse, is tested in Section VI. The second hypothesis, that riskier firms securitize more, is tested in Section VII. Finally, Section VIII concludes. 


\section{Background on SPVs}

In this section we briefly review some of the important institutional background for understanding SPVs and their relation to their sponsor.

\section{A. Legal Form of the SPV}

A special purpose vehicle or special purpose entity is a legal entity which has been set up for a specific, limited, purpose by another entity, the sponsoring firm. An SPV can take the form of a corporation, trust, partnership, or a limited liability company. The SPV may be a subsidiary of the sponsoring firm, or it may be an "orphan" SPV, one that is not consolidated with the sponsoring firm for tax, accounting, or legal purposes (or may be consolidated for some purposes but not others). ${ }^{7}$

Most commonly in securitization, the SPV takes the legal form of a trust. Traditionally, a trust is "a fiduciary relationship with respect to property, arising as a result of a manifestation of an intention to create that relationship and subjecting the person who holds title to the property [the trustee] to duties with it for the benefit of" third party beneficiaries (Restatement (Third) of Trusts). Often the SPV is a charitable or purpose trust. Traditional gratuitous or charitable trusts have been transformed into a vehicle with a different economic substance than perhaps contemplated by the law. These trusts, commercial trusts, are very different from gratuitous trusts (see Schwarcz (2003b), Langbein (1997), and Sitkoff (2003)).

A purpose trust (called a STAR trust in the Cayman Islands) is a trust set up to fulfill specific purposes rather than for beneficiaries. A charitable trust has charities as the beneficiaries. For many transactions there are benefits if the SPV is domiciled offshore, usually in Bermuda, the Cayman Islands, or the British Virgin Islands.

\section{B. Accounting}

\footnotetext{
${ }^{7}$ Interesting and important issues arise when the SPV and the sponsor are in different countries legally. This is often the case as the SPV is legally usually in a tax haven such as the Cayman Islands. Below we only briefly touch on these issues.
} 
A key question for an SPV (from the point of view of SPV sponsors, if not economists) is whether the SPV is off-balance sheet or not with respect to some other entity. This is an accounting issue, which turns on the question of whether the transfer of receivables from the sponsor to the SPV is treated as a sale or a loan for accounting purposes. ${ }^{8}$ The requirements for the transfer to be treated as a sale, and hence receive off-balance sheet treatment, are set out in Financial Accounting Standard No. 140 (FAS 140), “Accounting for Transfers and Servicing of Financial Assets and Extinguishment of Liabilities," promulgated in September 2000. ${ }^{9}$ FAS 140 essentially has two broad requirements for a "true sale." First, the SPV must be a "qualifying SPV" and second the sponsor must surrender control of the receivables.

In response to Enron's demise, the Federal Accounting Standard Board (FASB) adopted FASB Interpretation No. 46 (FIN 46) (revised December 2003), “Consolidation of Variable Interest Entities, an Interpretation of Accounting Research Bulletin (ARB) No. 51, which has the aim of improving financial reporting and disclosure by companies with variable interest entities (VIEs). ${ }^{10}$ Basically, FASB's view is that the then current accounting rules that determined whether an SPV should be consolidated were inadequate. Because FASB had difficulty defining an SPV, it created the VIE concept. FIN 46 sets forth a new measure of financial control, one not based on majority of voting interests, but based on who holds the majority of the residual risk and obtains the majority of the benefits, or both - independent of voting power.

A "qualifying" SPV (QSPV) is an SPV that meets the requirements set forth in FAS 140, otherwise it is treated as a VIE in accordance with FIN 46. FIN 46 does not apply to QSPVs. To be a qualifying SPV means that the vehicle: (1) is "demonstrably distinct" from the sponsor; (2) is significantly limited in its permitted activities, and these activities are entirely specified by the legal documents defining its existence; (3) holds only "passive" receivables, that is there are no decisions to be made; (4) has the right, if any, to sell or otherwise dispose of non-cash receivables only in "automatic response" to the occurrence of certain events. The term, "demonstrably distinct," means that the sponsor cannot have the ability to unilaterally dissolve the SPV, and that

\footnotetext{
${ }^{8}$ If the conditions of a sale are met, then the transferor must recognize a gain or loss on the sale.

${ }^{9}$ Prior to FAS 140 the issue was addressed by FAS 125 . FAS 140 was intended to clarify several outstanding question left ambiguous in FAS 125.

${ }^{10}$ VIEs are defined by FASB to be entities that do not have sufficient equity to finance their activities without additional subordinated support. It also includes entities where the equity holders do not have voting or other rights to make decisions about the entity, are not effectively residual claimants, and do not have the right to expected residual returns.
} 
at least ten percent of the fair value (of its beneficial interests) must be held by unrelated third parties.

On the second requirement of FAS 140, the important aspect of "surrendering control" is that the sponsor can not retain effective control over the transferred assets through an ability to unilaterally cause the SPV to return specific assets (other than through a cleanup call or to some extent 'removal of accounts provisions').

FAS 140 states that the sponsor need not include the debt of a qualifying SPV-subsidiary in the sponsor's consolidated financial statements.

A QSPV must be a separate and distinct legal entity, separate and distinct, that is, from the sponsor (the sponsor does not consolidate the SPV for accounting reasons). It must be an automaton in the sense that there are no substantive decisions for it to ever make, simply rules that must be followed; it must be bankruptcy remote, meaning that the bankruptcy of the sponsor has no implications for the SPV; and the SPV itself must (as a practical matter) never be able to become bankrupt.

\section{Bankruptcy}

An essential feature of an SPV is that it be "bankruptcy remote," that is, that the SPV never be able to become legally bankrupt. The most straightforward way to achieve this would be for the SPV to waive its right to file a voluntary bankruptcy petition, but this is legally unenforceable (see Klee and Butler (2002), p. 33 ff.). The only way to completely eliminate the risk of either voluntary or involuntary bankruptcy is to create the SPV in a legal form that is ineligible to be a debtor under the U.S. Bankruptcy Code. The SPV can be structured to achieve this result. As described by Klee and Butler (2002): "The use of SPVs is simply a disguised form of bankruptcy waiver" (p. 34).

To make the SPV as bankruptcy remote as possible, its activities can be restricted, for instance it can be restricted from issuing debt beyond a stated limit. Standard and Poor's (2002) lists the following traditional characteristics for a bankruptcy remote SPV:

- Restrictions on objects, powers, and purposes; 
- Limitations on ability to incur indebtedness;

- Restrictions or prohibitions on merger, consolidation, dissolution, liquidation, winding up, asset sales, transfers of equity interests, and amendments to the organizational documents relating to "separateness";

- Incorporation of separateness covenants restricting dealings with parents and affiliates;

- "Non-petition" language (i.e., a covenant not to file the SPE into involuntary bankruptcy);

- Security interests over assets; and

- An independent director (or functional equivalent) whose consent is required for the filing of a voluntary bankruptcy petition.

The SPV can also obtain agreements from its creditors that they will not file involuntary petitions for bankruptcy. Depending on the legal form of the SPV, it may require more structure to insure effective bankruptcy remoteness. For example, if the SPV is a corporation, where the power to file a voluntary bankruptcy petition lies with the board of directors, then the charter or by-laws can be structured to require unanimity. Sometimes charters or by-laws have provisions that negate the board's discretion unless certain other criteria are met.

An involuntary bankruptcy occurs under certain circumstances (see Section 303(b) of the Bankruptcy Code). Chief among the criteria is non payment of debts as they become due. Perhaps most important for securitization vehicles, shortfalls of cash leading to an inability to make promised coupon payments can lead to early amortization rather than an event of default on the debt. This is discussed further below.

There is also the risk that if the sponsor of the SPV goes bankrupt that the bankruptcy judge will recharacterize the "true sale" of assets to the SPV as a secured financing, which would bring the assets back onto the bankrupt sponsor's balance sheet. Or the court may consolidate the assets of the sponsor and the SPV. As a result of this risk, must structured financings have a two-tiered structure involving two SPVs. Often times the sponsor retains a residual interest in the SPV that provides a form of credit enhancement, but the residual interest may preclude a "true sale." Consequently, the residual interest is held by another SPV, not the sponsor. The "true sale" occurs with respect to this second vehicle. This is shown in Figure 1, which is taken from Moody's (August 30, 2002). 


\section{Taxes $^{11}$}

There are two tax issues. First, how is the SPV taxed? Second, what are the tax implications of the SPV's debt for the sponsoring firm? We briefly summarize the answers to these questions.

The first question is easier to answer. SPVs are usually structured so as to be tax neutral, that is, so that their profits are not taxed. The failure to achieve tax neutrality would usually result in taxes being imposed once on the income of the sponsor and once again on the distributions from the SPV. This "double tax" would most likely make SPVs unprofitable for the sponsor. There are a number of ways to design the SPV to achieve tax neutrality. We briefly review some of them.

Many SPVs are incorporated in a tax haven jurisdiction, such as the Cayman Islands, where they are treated as "exempted companies." See Ashman (2000). An exempted company is not permitted to conduct business in, for example, the Cayman Islands, and in return is awarded a total tax holiday for twenty years, with the possibility of a ten year extension. Because such entities are not organized or created in the U.S., they are not subject to U.S. federal income tax, except to the extent that their income arises from doing business in the U.S. However, the organizational documents for the SPV will limit it so that for purposes of the U.S. Internal Revenue Code of 1986, it can be construed as not being "engaged in U.S. trade or business."

An investment trust that issues pass-through certificates is tax neutral, that is, the trust is ignored for tax purposes - there is no taxation at the trust level - and the certificate owners are subject to tax. Pass-through certificates represent pro rata interests in the underlying pool. It is important for maintaining this tax neutral tax status that the SPV not be reclassified as a corporation. To avoid this it is necessary that the trustee have no power to vary the investments in the asset pool ands activities must be limited to conserving and protecting the assets for the benefit of the beneficiaries of the trust. See Kramer (2003).

More common than pass-through structures are pay-through structures. Pay-through bonds are issued by SPVs that are corporations or owner trusts. In these structures the SPVs issue bonds,

${ }^{11}$ This subsection is based on Kramer (2003), Peaslee and Nirenberg (2001), and Humphreys and Kreistman (1995). 
but this requires that there be a party that holds the residual risk, an equity holder. If the SPV is a corporation, then the pay-through bonds have minimal tax at the corporate level because the SPV's taxable income or loss is the difference between the yields on its assets and the coupons on its pay-through bonds. Typically these are matched as closely as possible.

The second question is more complicated. Some SPVs achieve off-balance sheet status for accounting purposes but not for tax purposes. Securitizations can fit into this category because they can be treated as secured financing for tax purposes.

\section{E. Credit Enhancement}

Because the SPV's business activities are constrained and its ability to incur debt is limited, it faces the risk of a shortfall of cash below what it is obligated to pay investors. This chance is minimized via credit enhancement. The most important form of credit enhancement occurs via tranching of the risk of loss due to default of the underlying borrowers. Tranching takes the form of a capital structure for the SPV, with some senior rated tranches sold to investors in the capital markets (called the A notes and the B notes), a junior security (called a $\mathrm{C}$ note) which is typically privately placed, and various forms of equity-like claims. Credit enhancement takes a variety of other forms as well, including over-collateralization, securities backed by a letter of credit, or a surety bond, or a tranche may be guaranteed by a monoline insurance company. There may also be internal reserve funds that build-up and diminish based on various criteria. We review this is more detail below with respect to credit card securitization in particular.

\section{F. The Use of Off-Balance Sheet Financing}

Off-balance sheet financing is, by definition, excluded from the sponsor's financial statement balance sheet, and so it is not reported systematically. Consequently, it is hard to say how extensive the use of SPVs has become. Qualified off-balance sheet SPVs that are used for asset securitization usually issue publicly rated debt and so there is more information about these vehicles. That data is presented and discussed below. SPVs that are not qualified, however, are hidden, as was revealed by the demise of Enron. Enron led to assertions that the use of offbalance sheet SPVs is extreme. ${ }^{12}$ But, in fact, the extent of the use of SPVs is unknown.

\footnotetext{
${ }^{12}$ For example, Henry, et al. (2002): "Hundreds of respected U.S. companies are ferreting away trillions of dollars in debt in off-balance sheet subsidiaries, partnerships, and assorted obligations."
} 


\section{Securitization}

Securitization is one of the more visible forms of the use of off-balance sheet SPVs because securitization uses qualified SPVs and involves selling registered, rated, securities in the capital markets. Consequently, there is data available. Our empirical work will concentrate on credit card receivables securitization. In this section we briefly review the important features of securitization SPVs.

\section{A. Overview of Securitization}

Securitization involves the following steps: (i) a sponsor or originator of receivables sets up the bankruptcy remote SPV, pools the receivables, and transfers them to the SPV as a "true sale"; (ii) the cash flows are tranched into asset-backed securities, the most senior of which are rated and issued in the market; the proceeds are used to purchase the receivables from the sponsor; (iii) the pool revolves in that over a period of time the principal received on the underlying receivables is used to purchase new receivables; (iv) there is a final amortization period, during which all payments received from the receivables are used to pay down tranche principal amounts. Credit card receivables are different from other pools of underlying loans because the underlying loan to the consumer is a revolving credit; it has no natural maturity, unlike an automobile loan, for example. Consequently, the maturity of the SPV debt is determined arbitrarily by stating that receivable payments after a certain date are "principal" payments.

Figure 2 shows a schematic drawing of a typical securitization transaction. The diagram shows the two key steps in the securitization process: pooling and tranching. Pooling and tranching correspond to different types of risk. Pooling minimizes the potential adverse selection problem associated with the selection of the assets to be sold to the SPV. Conditional on selection of the assets, tranching divides the risk of loss due to default based on seniority. That is, the SPV purchases these cash flows by issuing securities differentiated by seniority. This step is called "tranching" (from the French word for slice, tranche). Since tranching is based on seniority, the risk of loss due to default of the underlying assets is stratified, with the residual risks borne by the sponsor. Little risk transfer occurs in a securitization, assuming that the pooling and tranching are done properly. 
Securitization is a significant and growing phenomenon. Figure 3 and Table 1 provide some information on non-mortgage QSPV outstanding amounts. The figure shows that the liabilities of non-mortgage vehicles are just short of $\$ 1.8$ trillion. Table 1 shows the breakdown by type of receivable. Note that credit card receivables are the largest component of (non-mortgage) assetbacked securities. See Moody's (May 29, 2003) for a discussion of the spread of securitization structures internationally.

Closely related to securitization is asset-backed commercial paper (ABCP). Asset-backed commercial paper SPVs are called "conduits." ABCP conduits are bankruptcy-remote SPVs that finance the purchase of receivables primarily through issuing commercial paper. ${ }^{13} \mathrm{ABCP}$ conduits are also very large. The U.S. commercial paper market, as of August 2004, stood at $\$ 1.3$ trillion, having grown from $\$ 570$ billion in January 1991. Figure 4 shows the ratio of ABCP to total outstanding commercial paper over the last twelve years. ${ }^{14}$ Over half of the total consists of $\mathrm{ABCP}$

\section{B. The Structure of Securitization Vehicles}

Some of the details of the structure of credit-card securitization SPVs are important for the subsequent empirical work. These details are briefly reviewed in this section.

\section{a. Trusts - Master Trusts}

Securitization SPVs are invariably trusts. The sponsor transfers receivables to the trust for the benefit of the certificate holders, i.e., the investors in the SPV. Most trusts are Master Trusts, which allow for repeated transfers of new receivables, whenever the sponsor chooses. ${ }^{15}$ At each such instance, the trust issues a series of securities (trust certificates) to investors in the capital markets. Each series has an undivided interest in the assets and an allocable interest in the collections of the receivables in the master trust, based on the size of each series. Trust assets that

\footnotetext{
${ }^{13} \mathrm{ABCP}$ conduits can be multi-seller, meaning that the receivables in the conduit have been originated by different institutions.

${ }^{14}$ ABCP conduits are an interesting topic in the own right. See Moody's (1993), FitchIBCA (2001), Elmer (1999), Croke (2003), and Standard and Poor's (2002).

${ }^{15}$ A "discrete trust" is an SPV used for a single initial transfer of assets.
} 
have not been allocated to a series are called the "seller's interest," discussed below. See Schwarcz (2003a).

Master trusts can be "socialized" or "nonsocialized," two categories which generally refer to how the SPV waterfall works, i.e., how the receivables' cash flows are internally allocated. In nonsocialized trusts there is no reallocation of excess cash flow until each series is paid its full amount. Socialized trusts pay the trust's expenses, including the monthly interest to investors, based on the needs of individualized series. Generally, the socialized excess spread is socialized across all SPV notes issued by the trust. This means that should there be an early amortization event (discussed below), then all the notes go into early amortization. In a nonsocialized trust, the notes have their own separate excess spreads. See Standard and Poor's (n.d.) for details.

\section{b. Seller's Interest}

The "seller's interest" refers to the sponsor's ownership of trust assets that have not been allocated to any series of securities issued by the trust. The size of the seller's interest varies through time as the amounts of securities issued by the SPV changes and as the balance of principal receivables in the trust assets changes. The seller's interest is usually initially set at seven percent.

\section{c. Excess Spread and Early Amortization}

Asset-backed securities also have the general features that they involve "excess spread." The yield on the underlying loans that is paid into the trust should be high enough to cover the payment of interest on the asset-backed securities (ABS) tranches in addition to the servicing fees. Excess spread is generally defined as finance charges collections (i.e., the gross yield on the underlying receivables) minus certificate interest (paid to the holders of the SPV debt), servicing fees (paid to the servicer of the receivables, usually the sponsor), and charge-offs (due to default by the underlying borrowers) allocated to the series. For example:

\begin{tabular}{cc} 
Gross Yield on Portfolio & $18 \%$ \\
Investors' Weighted Avg. Coupon & $-7 \%$ \\
Servicing Expense & $-2 \%$ \\
Charge-Offs & $-5 \%$ \\
\hline Excess Spread & $4 \%$
\end{tabular}


Depending on the structure of the SPV, available excess spread may be shared with other series (in the Master Trust), used to pay credit enhancers, deposited into a reserve account to be used to cover charge-offs, or released to the sponsor.

Practitioners view the excess spread as providing a rough indication of the financial health of a transaction. Excess spread is in fact highly persistent and consequently can be used as a way to monitor a transaction.

All credit card structures have a series of early amortization triggers, which if hit cause the payments to investors to be defined as principal, so that the SPVs' liabilities are paid off early, that is, before the scheduled payment date. Early amortization events include insolvency of the originator of the receivables, breaches of representations or warranties, a service default, failure to add receivables as required, and others. Most importantly, however, a transaction will amortize early if the monthly excess spread falls to zero or below for three consecutive months.

\section{d. Credit Enhancement}

In the most common securitization structure the SPV issues tranches of securities to the capital markets based on seniority. There are senior notes, called A notes, and junior or mezzanine note called B notes. A common form of credit enhancement to the more senior classes, A notes and B notes, is a subordinated interest known as the collateral invested amount (CIA). The most subordinated interest is referred to by a number of different names, including the $\mathrm{C}$ class, $\mathrm{C}$ note, or collateral interest. ${ }^{16}$ As mentioned above, $\mathrm{C}$ notes are typically privately placed. This is partly because they are riskier, but also because they do not qualify as debt for tax purposes making them ERISA-ineligible. Because they are privately placed, they are not rated, and much less information is available about them. See Moody's (November 11, 1994) on C notes.

Credit enhancement for the CIA is a reserve account, which grows depending on the level of the excess spread. If the excess spread is low, then excess spread is trapped inside the SPV and used to build up the reserve account to a specified level. Reserve account structures vary, with

\footnotetext{
${ }^{16}$ Prior to the development and widespread use of CIAs, credit card transactions employed letters of credit (LOCs) from highly rated institutions to protect investors against default. CIAs became prevalent as a way to avoid dependency on the LOC issuer's credit quality.
} 
different structures having different amounts of excess spread trapped inside the trust depending on different contingencies. If the excess spread is negative, the reserve account is drawn down to make up the shortfall.

\section{Implicit Recourse}

There are examples of recourse in credit card securitizations that are known publicly. Moody's (January 1997) gives fourteen examples of "notable instances" of voluntary support. The earliest example is from May 1989 and the latest listed is November 1996. Higgins and Mason (2004) study a sample of 17 implicit recourse events involving ten banks, during the period 1987 to 2001. ${ }^{17}$ Higgins and Mason document that firms that engage in subsidization of their SPVs "face long delays before returning to market."

\section{An SPV Game}

In this section we analyze a simple model of off-balance sheet financing, a game played between a representative firm (the sponsor of the SPV) and a large number of investors. The goal is to understand the source of value in the use of SPVs.

For concreteness we call the sponsoring firm a bank, by which we mean any financial intermediary or, indeed, any firm. We proceed by first setting out a model of the bank financing a portfolio of projects in a one period setting. The bank's efforts determine the quality of the projects, unbeknownst to the lenders to the bank. Project quality is implicitly determined by various activities of banks, including information production, screening, and monitoring, but for simplicity it is modeled as an "effort" choice by the bank. ${ }^{18}$ This provides a benchmark against which we can determine the value of securitization in the one period setting.

We will subsequently allow for the possibility of securitization, where one project may be financed off-balance sheet in an SPV. The timing is as follows: projects are allocated to be

\footnotetext{
${ }^{17}$ During the period 1987-2001 Higgins and Mason (2004) report two instances of early amortization, both associated with the failure of the sponsoring institution, namely, Republic Bank and Southeast Bank.

${ }^{18}$ See Gorton and Winton (2003) for a review of the literature on banks' information production, screening, and monitoring activities.
} 
financed on- or off-balance sheet, and then the bank makes a single effort choice that determines the quality of both the on- and off-balance sheet projects. To emphasize, projects are allocated first, and then project quality is realized. So, the focus at this point is on the moral hazard problem involving effort choice, rather than on the strategic allocation of projects after their qualities are known (i.e., the adverse selection problem). By comparing the value of the bank when securitization is allowed to the benchmark bank value when there is no securitization, we determine the factors causing securitization to be valuable.

Finally, we will allow for strategic allocation of the two projects, i.e., projects are allocated between the balance sheet of the bank and the balance sheet of the SPV after their qualities are known. Bank project quality choice is the agency problem that lenders to the bank and to the SPV are concerned about. If projects are allocated between the bank and the SPV before the project's type is realized there is no strategic adverse selection problem. The possibility of strategic allocation of projects adds an additional problem that investors must be concerned about. In this setting, the bank cannot commit to allocate a high type project to the SPV. In the credit card case there are some constraints on the lemons issue because accounts to be sold to the trust are supposed to be chosen randomly. In this case, the adverse selection may have more to do with timing of the addition of accounts depending on the state of the on-balance sheet assets, or perhaps with the removal of accounts. ${ }^{19}$

Without the ability to commit to transfer a high quality project to the SPV we show that no lender will lend to the SPV. Off-balance sheet financing, or securitization, in this setting is not possible. This sets the stage for the repeated SPV game, analyzed briefly in the final part of this section. The point there is that repetition of the stage game between the bank and the outside investors can create equilibria in which an implicit contractual arrangement involving bailouts of the SPV by the sponsoring bank can be enforced. By "bailouts" we mean extra-contractual support for the $\mathrm{SPV}$, as will become clear below.

\section{A. Model Set-Up}

\footnotetext{
${ }^{19}$ Also, sometimes sponsors add "high quality" accounts to improve the overall quality of the receivables pool.
} 
A competitive bank seeks to finance two one-period nondivisible projects. Each project requires $\$ 1$ of investment. The bank has an amount $\$ E<2$ available to finance the two projects. Since $\mathrm{E}<2$, the bank must borrow $\mathrm{D}=2-\mathrm{E}$, promising to repay $\mathrm{F}$ at the end of the period. Debt, however, is tax advantaged, so only $(1-\tau) \mathrm{F}$ needs to be repaid, where $\tau$ is the relevant tax rate. The interest rate $\mathrm{r}$ in the economy is for simplicity assumed to be zero.

We analyze a representative bank and a unit interval of investors. All agents, i.e., the banks and the investors, are risk-neutral. Consumption occurs at the end of the period.

The bank determines the quality of its projects by expending "effort," $e \in\left\{e_{H}, e_{L}\right\}$, where $e_{H}>e_{L}$, and such that a project returns $\mathrm{y}^{\mathrm{H}}$ with probability e and $\mathrm{y}^{\mathrm{L}}$ with probability $(1-e)$, where $\mathrm{y}^{\mathrm{H}}>\mathrm{y}^{\mathrm{L}}$. The single effort choice determines the qualities of both projects, but project realizations are independent. Thus, there are four possible outcomes or states of the world at the end of the period: $\left\{\mathrm{y}^{\mathrm{H}}, \mathrm{y}^{\mathrm{H}}\right\},\left\{\mathrm{y}^{\mathrm{H}}, \mathrm{y}^{\mathrm{L}}\right\},\left\{\mathrm{y}^{\mathrm{L}}, \mathrm{y}^{\mathrm{H}}\right\}$, and $\left\{\mathrm{y}^{\mathrm{L}}, \mathrm{y}^{\mathrm{L}}\right\}$. The single effort costs $\mathrm{h}(\mathrm{e})$. "Effort" is to be interpreted as the resources necessary to produce information about a project and to monitor it. Effort is not contractible.

Projects satisfy the following assumptions:

A1. $2\left[e_{H} y^{H}+\left(1-e_{H}\right) y^{L}\right]-h\left(e_{H}\right)>D$, i.e., a project is a positive net present value investment when a high effort level is chosen, i.e., $\mathrm{e}=\mathrm{e}_{\mathrm{H}}$.

A2. $2\left[e_{L} y^{H}+\left(1-e_{L}\right) y^{L}\right]-h\left(e_{L}\right)<D$, i.e., a project is a negative net present value investment when a low effort choice is made, i.e., $\mathrm{e}=\mathrm{e}_{\mathrm{L}}$.

A3. $2 y^{L}-h(e)<F$, for $e \in\left\{e_{H}, e_{L}\right\}$, i.e., default is certain if each project returns $y^{L}$ (state $\left\{y^{L}\right.$, $\left.\left.y^{\mathrm{L}}\right\}\right)$.

A4. $2 y^{H}-h(e)>y^{H}+y^{L}-h(e)>F$, for $e \in\left\{e_{H}, e_{L}\right\}$, i.e., default does not occur in the other states.

Assumptions A3 and A4 are stated in terms of the face value of the debt, F, which is an endogenous variable. Nevertheless, the point of A3 and A4 is to determine the states of the world when default occurs. Default occurs only in the state $\left\{y^{\mathrm{L}}, \mathrm{y}^{\mathrm{L}}\right\}$. We will subsequently solve for the equilibrium $\mathrm{F}$ under this assumption and then verify that that value of $\mathrm{F}$ is consistent with 
assumptions A3 and A4 when $\mathrm{F}$ is eliminated through substitution; the assumptions can then be stated entirely in terms of primitives.

Corporations face a proportional bankruptcy cost, proportional to the realized output. In other words, larger firms have higher bankruptcy costs. This cost is borne by the creditors. The reason that the bankruptcy cost is proportional, rather than lump-sum, is not only realism, but it also simplifies the model, as will become clear below. The bankruptcy cost is $c \in(0,1)$ per unit of output. A fixed bankruptcy cost could be added to this, though with binomial outcomes it has no additional content. The bankruptcy cost is discussed further below.

On-balance sheet debt has a tax advantage. Off-balance sheet debt usually does not have this advantage. Here the cost of using off-balance sheet debt is the loss of the tax shield to the sponsoring firm. The sponsor may structure the SPV so that this cost does not exist. In that case, we would point to other costs. In general, some limit to how much can be financed off-balance sheet is needed for there to be an interior solution. However, recent "whole-firm" securitizations suggest that there may be few limits. See Pfister (2000).

\section{B. Discussion of the Model}

The model provides a role for the bank; it has the unique ability to find high quality projects by making an effort. However, this value production is not observable to outside investors since they cannot confirm the effort level chosen by the bank. This is essentially the usual model of bank activity. We assume that the bank issues debt to outside investors, and do not explain why debt is the security of choice. Any firm transferring assets off-balance sheet has created assets of a certain value, which may not be known to outside investors, so the "bank" need not literally be taken to exclude nonfinancial firms.

\section{The Benchmark Case of No Securitization}

We begin with the benchmark problem of the bank when there is no off-balance securitization. In that case, the bank's problem is to choose $\mathrm{F}$ and $\mathrm{e} \in\left\{\mathrm{e}_{\mathrm{H}}, \mathrm{e}_{\mathrm{L}}\right\}$ to maximize the expected value of its projects:

$$
\max : V=e^{2}\left[2 y^{H}-h(e)-(1-\tau) F\right]+2 e(1-e)\left[y^{H}+y^{L}-h(e)-(1-\tau) F\right]
$$


subject to:

$$
\text { (ii) } \mathrm{V}\left(\mathrm{e}=\mathrm{e}_{\mathrm{H}} ; \mathrm{e}_{0}=\mathrm{e}_{\mathrm{H}}\right) \geq \mathrm{V}\left(\mathrm{e}=\mathrm{e}_{\mathrm{L}} ; \mathrm{e}_{0}=\mathrm{e}_{\mathrm{H}}\right) \quad \text { (Incentive Compatibility) }
$$

The first constraint says that the expected pay-off to the investors who purchase the bank debt, $\mathrm{E}(\mathrm{F})$, must be at least what was lent (D), otherwise the risk neutral investors will not lend to the bank (since the interest rate is zero). The second constraint says that if investors lend to the bank believing that the bank will choose effort level $\mathrm{e}_{\mathrm{H}}$, where $\mathrm{e}_{0}$ is the belief of the lenders regarding the bank's effort choice, then the bank behaves consistently with these beliefs, choosing $\mathrm{e}=\mathrm{e}_{\mathrm{H}}$.

The optimization problem is written assuming that the bank defaults only in state $\left\{y^{\mathrm{L}}, \mathrm{y}^{\mathrm{L}}\right\}$ as assumed above by A3 and A4.

Note that the Participation Constraint can be written as follows, since investors get only the remaining cash flows net of the bankruptcy and effort costs:

$$
\left[e^{2}+2 e(1-e)\right] F+(1-e)^{2}\left[2 y^{L}(1-c)-h(e)\right] \geq D
$$

Suppose investors' beliefs about the bank's effort choice are $\mathrm{e}=\mathrm{e}_{0}$. Then the lowest promised repayment amount that lenders will accept, in order to lend is:

$$
F_{0}=\frac{D-\left(1-e_{0}\right)^{2}\left[2 y^{L}(1-c)-h\left(e_{0}\right)\right]}{e_{0}\left(2-e_{0}\right)} .
$$

Substitute this into the bank's problem; the bank's problem is now to choose $e \in\left\{e_{H}, e_{L}\right\}$ to:

$$
\max V=2 e y^{H}+2 e(1-e) y^{L}-e(2-e) h(e)-(1-\tau) e(2-e)\left[\frac{D-\left(1-e_{0}\right)^{2}\left[2 y^{L}(1-c)-h\left(e_{0}\right)\right]}{e_{0}\left(2-e_{0}\right)}\right]
$$

subject to:

(ii) $V\left(e=e_{H} ; e_{0}=e_{H}\right) \geq V\left(e=e_{L} ; e_{0}=e_{H}\right)$

(Incentive Compatibility). 
Incentive compatibility requires that the bank's choice of $e \in\left\{e_{H}, e_{L}\right\}$ be the same as what the lenders believe it will be, namely $\mathrm{e}_{0}$. Suppose that beliefs are consistent, i.e., that $\mathrm{e}=\mathrm{e}_{0}=\mathrm{e}_{\mathrm{H}}$. Then, indicating bank value by $\mathrm{V}^{\mathrm{H}}$, we have:

$V^{H}=2 e_{H} y^{H}+2 e_{H}\left(1-e_{H}\right) y^{L}-e_{H}\left(2-e_{H}\right) h\left(e_{H}\right)-(1-\tau)\left[D-\left(1-e_{H}\right)^{2}\left(2 y^{L}(1-c)-h\left(e_{H}\right)\right)\right]$.

If beliefs were inconsistent, that is, if lenders' beliefs were $e_{0}=e_{H}$, but the bank chose $e=e_{L}$, then the value of the bank is given by:

$$
\begin{aligned}
\mathrm{V}\left(\mathrm{e}=\mathrm{e}_{\mathrm{L}}\right. & \left.; \mathrm{e}_{0}=\mathrm{e}_{\mathrm{H}}\right)=2 \mathrm{e}_{\mathrm{L}} \mathrm{y}^{\mathrm{H}}+2 \mathrm{e}_{\mathrm{L}}\left(1-\mathrm{e}_{\mathrm{L}}\right) \mathrm{y}^{\mathrm{L}}-\mathrm{e}_{\mathrm{L}}\left(2-\mathrm{e}_{\mathrm{L}}\right) \mathrm{h}\left(\mathrm{e}_{\mathrm{L}}\right) \\
& -(1-\tau) e_{L}\left(2-e_{L}\right)\left[\frac{D-\left(1-e_{H}\right)^{2}\left(2 y^{L}(1-c)-h\left(e_{H}\right)\right.}{e_{H}\left(2-e_{H}\right)}\right]
\end{aligned}
$$

\section{Lemma 1: If:}

$$
\begin{aligned}
2 y^{H}\left(e_{H}-e_{L}\right)+2 y^{L}\left[e_{H}\left(1-e_{H}\right)\right. & \left.-e_{L}\left(1-e_{L}\right)\right]-h\left(e_{H}\right) e_{H}\left(2-e_{H}\right)+h\left(e_{L}\right) e_{L}\left(2-e_{L}\right) \\
& -(1-\tau)\left[D-\left(1-e_{H}\right)^{2}\left[2 y^{L}(1-c)-h\left(e_{H}\right)\right]\left[1-\frac{e_{L}\left(2-e_{L}\right)}{e_{H}\left(2-e_{H}\right)}\right]>0,\right.
\end{aligned}
$$

then at the optimum, investors believe $\mathrm{e}_{0}=\mathrm{e}_{\mathrm{H}}$ and the bank chooses $\mathrm{e}=\mathrm{e}_{\mathrm{H}}$. The value of the bank is given by (1).

Proof: The incentive compatibility constraint, $V\left(e=e_{H} ; e_{0}=e_{H}\right) \geq V\left(e=e_{L} ; e_{0}=e_{H}\right)$, is satisfied if the condition in the lemma holds. It remains to verify that the equilibrium $\mathrm{F}$ derived under $\mathrm{A} 3$ and A4 is consistent, i.e., to state A3 and A4 in terms of primitives. That is left to the Appendix. //

In what follows we will refer to $\mathrm{V}^{\mathrm{H}}$ as the value of the bank when there is no securitization. This will be the benchmark value against which the value of the bank with securitization will be compared. 


\section{Special Purpose Vehicles and Securitization}

Now, suppose the bank sets up a special purpose vehicle (SPV) to finance one of the projects. One project will be financed on-balance sheet, and one will be financed off-balance sheet. ${ }^{20}$ The SPV has no bankruptcy costs, as discussed above, and its debt has no tax advantage. The effort choice is made at the bank level and determines the qualities of both projects, though the outcomes are independent, as before. ${ }^{21}$ To be clear, the projects are first allocated to be on- or off-balance sheet, and then the bank makes its effort choice.

On-balance sheet the bank will borrow $0.5 \mathrm{D}$, promising to repay $\mathrm{F}^{\mathrm{B}}$ at the end of the period. Offbalance sheet, the SPV will borrow $0.5 \mathrm{D}$, promising to repay $\mathrm{F}^{\mathrm{S}}$ at the end of the period. ${ }^{22}$ The bank then has two assets on-balance sheet, its own project, and an equity claim on the SPV, i.e., if $y$ is the realization of the SPV's project, then the bank's equity claim on the SPV at the end of the period is $\max \left[y-\mathrm{F}^{\mathrm{S}}, 0\right]{ }^{23}$

Assumptions analogous to A3 and A4, above, define the bankruptcy states:

A3a. $2 y^{L}-h(e)<F^{B}+F^{S}$, for $e \in\left\{e_{H}, e_{L}\right\}$, i.e., default of both the bank and the SPV occurs if the realized state of the world is $\left\{\mathrm{y}^{\mathrm{L}}, \mathrm{y}^{\mathrm{L}}\right\}$.

A4a. $2 y^{H}-h(e)>y^{H}+y^{L}-h(e)>F^{B}+F^{S}$, for $e \in\left\{e_{H}, e_{L}\right\}$, i.e., there need not be default of either entity in the other states.

As before assumptions $\mathrm{A} 3 \mathrm{a}$ and $\mathrm{A} 4 \mathrm{a}$ are stated in terms of $\mathrm{F}^{\mathrm{B}}$ and $\mathrm{F}^{\mathrm{S}}$, endogenous variables. Assumption A3a determines the states of the world when default definitely will occur, namely, in state $\left\{y^{\mathrm{L}}, \mathrm{y}^{\mathrm{L}}\right\}$. A4a states that the two projects generate sufficient payoffs in the other states to

\footnotetext{
${ }^{20}$ This is assumption is made for simplicity. The model does not determine the scale of the SPV.

${ }^{21}$ Note that no effort choice can be made by the SPV, as it is passive. If the effort choice could be made at that level, the entity would be a subsidiary of the bank, rather than an SPV.

${ }^{22}$ For simplicity other financing choices are assumed to not be available. While we do not model tranching, it is not inconsistent with the model to allow for additional motivations for securitization beyond those we consider, such as clientele effects (e.g., perhaps due to ERISA-eligibility requirements) .

${ }^{23}$ Strictly speaking there is an intermediate step because the bank funds both projects initially on-balance sheet and then transfers one, in a true sale, to the SPV. We assume that the proceeds from selling the project to the SPV are used to pay down on-balance sheet debt. For simplicity, this step is omitted.
} 
avoid bankruptcy, though whether that is the outcome or not will depend on the relationship between the bank and the SPV. We will subsequently solve for the equilibrium $\mathrm{F}^{\mathrm{B}}$ and $\mathrm{F}^{\mathrm{S}}$ under these assumptions and then verify that those values of $\mathrm{F}^{\mathrm{B}}$ and $\mathrm{F}^{\mathrm{S}}$ are consistent with assumptions $\mathrm{A} 3 \mathrm{a}$ and $\mathrm{A} 4 \mathrm{a}$ when $\mathrm{F}$ is eliminated through substitution; the assumptions can then be stated entirely in terms of primitives.

We also now assume:

A5. $\left(1-e_{H}\right)^{2} y^{L}(1-c)<0.5 D$, i.e., the expected return for the bank, from the on-balance sheet project, in the bankruptcy state $\left\{y^{\mathrm{L}}, \mathrm{y}^{\mathrm{L}}\right\}$ (which occurs with probability $\left.\left(1-\mathrm{e}_{\mathrm{H}}\right)^{2}\right)$ is insufficient to pay $0.5 \mathrm{D}$, the amount borrowed.

At the end of the period, by A3a and A4a, the possible outcomes are as follows, where the first element is the on-balance sheet project state realization and the second element is the off-balance sheet project state realization:

- $\left\{\mathrm{y}^{\mathrm{H}}, \mathrm{y}^{\mathrm{H}}\right\}$ : Both projects realize $\mathrm{y}^{\mathrm{H}}$; this occurs with probability $\mathrm{e}^{2}, \mathrm{e} \in\left\{\mathrm{e}_{\mathrm{H}}, \mathrm{e}_{\mathrm{L}}\right\}$. In this event, both on- and off-balance sheet debts can be repaid in full.

- $\quad\left\{\mathrm{y}^{\mathrm{H}}, \mathrm{y}^{\mathrm{L}}\right\}$ : The on-balance sheet project realizes $\mathrm{y}^{\mathrm{H}}$, and the SPV's project is worth $\mathrm{y}^{\mathrm{L}}$. This occurs with probability $\mathrm{e}(1-\mathrm{e}), \mathrm{e} \in\left\{\mathrm{e}_{\mathrm{H}}, \mathrm{e}_{\mathrm{L}}\right\}$. The bank is solvent, but the SPV defaults on its debt.

- $\quad\left\{y^{\mathrm{L}}, \mathrm{y}^{\mathrm{H}}\right\}$ : The off-balance sheet project realizes $\mathrm{y}^{\mathrm{H}}$, but the bank's project is worth $\mathrm{y}^{\mathrm{L}}$. This occurs with probability $\mathrm{e}(1-\mathrm{e}), \mathrm{e} \in\left\{\mathrm{e}_{\mathrm{H}}, \mathrm{e}_{\mathrm{L}}\right\}$. The SPV can honor its debt, and so can the bank because the bank is the equity holder of the SPV.

- $\left\{\mathrm{y}^{\mathrm{L}}, \mathrm{y}^{\mathrm{L}}\right\}:$ Both projects realize $\mathrm{y}^{\mathrm{L}}$; this occurs with probability (1-e $)^{2}, e \in\left\{\mathrm{e}_{\mathrm{H}}, \mathrm{e}_{\mathrm{L}}\right\}$. Neither the bank nor the SPV can honor their debt.

Note that with or without securitization, the bank fails only if the realized state is $\left\{\mathrm{y}^{\mathrm{L}}, \mathrm{y}^{\mathrm{L}}\right\}$. Consequently, with only two states a lump-sum bankruptcy cost would always be borne in this, and only this, state. This is due to the simplicity of the model. However, the proportional bankruptcy cost will be affected by securitization since the on-balance sheet assets have been reduced to one project. In a more complicated model, with a continuous range of project 
realizations, a fixed bankruptcy cost could be borne as a function of the bank's leverage, which could be chosen endogenously. Here, the simplicity of the model dictates use of a proportional bankruptcy cost. But, clearly this is not essential for the main point.

The bank's problem is to choose $\mathrm{F}^{\mathrm{B}}, \mathrm{F}^{\mathrm{S}}$, and $\mathrm{e} \in\left\{\mathrm{e}_{\mathrm{H}}, \mathrm{e}_{\mathrm{L}}\right\}$ to:

$$
\begin{aligned}
& \max \mathrm{V}^{\mathrm{S}}=\mathrm{e}^{2}\left[2 \mathrm{y}^{\mathrm{H}}-\mathrm{h}(\mathrm{e})-(1-\tau) \mathrm{F}^{\mathrm{B}}-\mathrm{F}^{\mathrm{S}}\right]+\mathrm{e}(1-\mathrm{e})\left[\mathrm{y}^{\mathrm{L}}+\mathrm{y}^{\mathrm{H}}-\mathrm{h}(\mathrm{e})-(1-\tau) \mathrm{F}^{\mathrm{B}}-\mathrm{F}^{\mathrm{S}}\right] \\
& +\mathrm{e}(1-\mathrm{e})\left[\mathrm{y}^{\mathrm{H}}-\mathrm{h}(\mathrm{e})-(1-\tau) \mathrm{F}^{\mathrm{B}}\right] \\
& \text { s.t. } \quad \text { (Participation of Investors in the Bank) } \\
& \begin{array}{ll}
\text { (i) } \quad \mathrm{E}\left[\mathrm{F}^{\mathrm{B}}\right] \geq 0.5 \mathrm{D} & \text { (Participation of Investors to the SPV) } \\
\text { (ii) } \mathrm{E}\left[\mathrm{F}^{\mathrm{S}}\right] \geq 0.5 \mathrm{D} & \\
\text { (iii) } \mathrm{V}^{\mathrm{S}}\left(\mathrm{e}=\mathrm{e}_{\mathrm{H}} ; \mathrm{e}_{0}=\mathrm{e}_{\mathrm{H}}\right) \geq \mathrm{V}^{\mathrm{S}}\left(\mathrm{e}=\mathrm{e}_{\mathrm{L}} ; \mathrm{e}_{0}=\mathrm{e}_{\mathrm{H}}\right) & \text { (Incentive Compatibility) }
\end{array}
\end{aligned}
$$

Note that (i) can be written as:

$$
\mathrm{e}(2-\mathrm{e}) \mathrm{F}^{\mathrm{B}}+(1-\mathrm{e})^{2}\left[\mathrm{y}^{\mathrm{L}}(1-\mathrm{c})-\mathrm{h}(\mathrm{e})\right] \geq 0.5 \mathrm{D}
$$

Similarly, (ii) can be written as:

$$
\mathrm{eF}^{\mathrm{S}}+(1-\mathrm{e}) \mathrm{y}^{\mathrm{L}} \geq 0.5 \mathrm{D}
$$

As before suppose lenders' beliefs are $\mathrm{e}_{0}$. Then investors in the bank and SPV, respectively, will participate if the promised repayments are at least:

$$
\mathrm{F}_{0}^{\mathrm{B}}=\frac{0.5 \mathrm{D}-\left(1-\mathrm{e}_{0}\right)^{2}\left[\mathrm{y}^{\mathrm{L}}(1-\mathrm{c})-\mathrm{h}\left(\mathrm{e}_{0}\right)\right]}{\mathrm{e}_{0}\left(2-\mathrm{e}_{0}\right)},
$$

and

$$
\mathrm{F}_{0}^{\mathrm{S}}=\frac{0.5 \mathrm{D}-\left(1-\mathrm{e}_{0}\right) \mathrm{y}^{\mathrm{L}}}{\mathrm{e}_{0}}
$$


Substitute these into the bank's problem. Then the bank's problem is to choose $e \in\left\{e_{H}, e_{L}\right\}$ to:

$$
\begin{aligned}
\max V^{S}=2 e y^{H}+e & (1-e) y^{L}-e(2-e) h(e)-(1-\tau) e(2-e)\left[\frac{0.5 D-\left(1-e_{0}\right)^{2}\left[y^{L}(1-c)-h\left(e_{0}\right)\right]}{e_{0}\left(2-e_{0}\right)}\right] \\
& -e\left[\frac{0.5 D-\left(1-e_{0}\right) y^{L}}{e_{0}}\right]
\end{aligned}
$$

s.t. (iii) $\mathrm{V}^{\mathrm{S}}\left(\mathrm{e}=\mathrm{e}_{\mathrm{H}} ; \mathrm{e}_{0}=\mathrm{e}_{\mathrm{H}}\right) \geq \mathrm{V}^{\mathrm{S}}\left(\mathrm{e}=\mathrm{e}_{\mathrm{L}} ; \mathrm{e}_{0}=\mathrm{e}_{\mathrm{H}}\right) \quad$ (Incentive Compatibility)

Suppose that beliefs are consistent, i.e., that $\mathrm{e}=\mathrm{e}_{0}=\mathrm{e}_{\mathrm{H}}$. Then:

$$
\begin{aligned}
V^{S}=2 e_{H} y^{H}+e_{H}\left(1-e_{H}\right) y^{L}-e_{H}\left(2-e_{H}\right) h\left(e_{H}\right)-(1-\tau)\left[0.5 D-\left(1-e_{H}\right)^{2}\left[y^{L}(1-c)-h\left(e_{H}\right)\right]\right. \\
-\left[0.5 D-\left(1-e_{H}\right) y^{L}\right] .
\end{aligned}
$$

\section{Lemma 2: If}

$$
\begin{aligned}
& 2 y^{H}\left(e_{H}-e_{L}\right)+y^{L}\left[e_{H}\left(1-e_{H}\right)-e_{L}\left(1-e_{L}\right)\right]-h\left(e_{H}\right) e_{H}\left(2-e_{H}\right)+h\left(e_{L}\right) e_{L}\left(2-e_{L}\right) \\
&-(1-\tau)\left[0.5 D-\left(1-e_{H}\right)^{2}\left[y^{L}(1-c)-h\left(e_{H}\right)\right]\left[1-\frac{e_{L}\left(2-e_{L}\right)}{e_{H}\left(2-e_{H}\right)}\right]>0\right.
\end{aligned}
$$

then at the optimum, lenders believe $\mathrm{e}_{0}=\mathrm{e}_{\mathrm{H}}$ and the bank chooses $\mathrm{e}=\mathrm{e}_{\mathrm{H}}$. The value of the bank is given by (2).

Proof: The incentive compatibility constraint, $\mathrm{V}^{\mathrm{S}}\left(\mathrm{e}=\mathrm{e}_{\mathrm{H}} ; \mathrm{e}_{0}=\mathrm{e}_{\mathrm{H}}\right) \geq \mathrm{V}^{\mathrm{S}}\left(\mathrm{e}=\mathrm{e}_{\mathrm{L}} ; \mathrm{e}_{0}=\mathrm{e}_{\mathrm{H}}\right)$, is satisfied if the condition in the lemma holds. It remains to verify that the equilibrium $\mathrm{F}^{\mathrm{B}}$ and $\mathrm{F}^{\mathrm{S}}$ derived under $\mathrm{A} 3 \mathrm{a}$ and $\mathrm{A} 4 \mathrm{a}$ are consistent, i.e., to state $\mathrm{A} 3 \mathrm{a}$ and $\mathrm{A} 4 \mathrm{a}$ in terms of primitives. That is left to the Appendix. // 
Proposition 1: If $\left(1-\mathrm{e}_{\mathrm{H}}\right)^{2} \mathrm{y}^{\mathrm{L}} \mathrm{c}-\tau\left[0.5 \mathrm{D}-\left(1-\mathrm{e}_{\mathrm{H}}\right)^{2} \mathrm{y}^{\mathrm{L}}(1-\mathrm{c})\right]>0$, then it is optimal for the bank to use the SPV to finance one project.

Proof: The condition in the proposition is a simplification of $\mathrm{V}^{\mathrm{S}}-\mathrm{V}^{\mathrm{H}}>0$. //

The factors that effect the profitability of securitization are taxes $(\tau)$, the bankruptcy cost (c), and risk, as measured by $\left(1-e_{H}\right)^{2}$, i.e., the chance of bankruptcy occurring. Taxes matter, to the extent that bankruptcy does not occur, because debt issued by the SPV is not tax advantaged (by assumption). The bankruptcy cost matters because expected bankruptcy costs are reduced to the extent that projects are financed off-balance sheet. This is due to the legal structure of the SPV. Finally, the risk of bankruptcy, $\left(1-\mathrm{e}_{\mathrm{H}}\right)^{2}$, makes the chance of incurring the bankruptcy cost higher.

Corollary 1: The profitability of off-balance sheet financing is increasing in the bankruptcy cost, $\mathrm{c}$, decreasing in the tax rate, $\tau$, and increasing in the riskiness of the project (i.e., the chance of bankruptcy), $\left(1-\mathrm{e}_{\mathrm{H}}\right)^{2}$.

Proof: The derivatives of $\mathrm{V}^{\mathrm{S}}-\mathrm{V}^{\mathrm{H}}$ with respect to $\mathrm{c}, \tau$, and $\left(1-\mathrm{e}_{\mathrm{H}}\right)^{2}$, respectively, are:

$$
\begin{aligned}
& \frac{\partial\left(V^{S}-V^{H}\right)}{\partial \tau}=-\left[0.5 D-\left(1-e_{H}\right)^{2} y^{L}(1-c)\right]<0, \text { by A.5. } \\
& \frac{\partial\left(V^{S}-V^{H}\right)}{\partial c}=\left(1-e_{H}\right)^{2} y^{L}(1-\tau)>0 . \\
& \frac{\partial\left(V^{S}-V^{H}\right)}{\partial\left(1-e_{H}\right)^{2}}=(1-\tau) c y^{L}+\tau y^{L}>0 .
\end{aligned}
$$

Corollary 1 identifies the basic drivers of SPV value, under the assumption that the projects are allocated to on- or off- balance sheet before their quality if known, i.e., there is no adverse selection.

\section{E. Securitization with Moral Hazard and Strategic Adverse Selection}

Now, suppose that the bank makes an effort choice, i.e., $e \in\left\{\mathrm{e}_{\mathrm{H}}, \mathrm{e}_{\mathrm{L}}\right\}$, but then after observing the realized project qualities, one of the projects is allocated to the SPV. Recall that project quality is 
not verifiable. This means that investors in the debt issued by the SPV face an additional problem. In addition to the moral hazard associated with the effort choice, there is an adverse selection problem with regard to which project is allocated to the SPV. Call this problem the "strategic adverse selection problem."

For this subsection we will also assume:

A6. $\mathrm{e}_{\mathrm{H}}^{2} \mathrm{y}^{\mathrm{H}}+\left(1-\mathrm{e}_{\mathrm{H}}^{2}\right) \mathrm{y}^{\mathrm{L}}<0.5 \mathrm{D}$.

The meaning of A6 will become clear shortly.

With the possibility of strategic adverse selection, at the end of the period, the possible outcomes (following A3a and A4a) are as follows:

- $\quad\left\{\mathrm{y}^{\mathrm{H}}, \mathrm{y}^{\mathrm{H}}\right\}$ : Both projects realize $\mathrm{y}^{\mathrm{H}}$; this occurs with probability $\mathrm{e}^{2}$. The bank allocates one of the $\mathrm{y}^{\mathrm{H}}$ projects to the SPV and retains the other one on-balance sheet. Both on- and off-balance sheet debts can be repaid in full.

- $\quad\left\{y^{\mathrm{H}}, \mathrm{y}^{\mathrm{L}}\right\}$ and $\left\{\mathrm{y}^{\mathrm{L}}, \mathrm{y}^{\mathrm{H}}\right\}$ : The realization of projects is: one $\mathrm{y}^{\mathrm{H}}$ and one $\mathrm{y}^{\mathrm{L}}$. This occurs with probability $2 \mathrm{e}(1-\mathrm{e})$. In both of these states of the world, the bank keeps the $\mathrm{y}^{\mathrm{H}}$ project on-balance sheet and allocates the $\mathrm{y}^{\mathrm{L}}$ project to the SPV. The bank is solvent, but the SPV defaults on its debt.

- $\quad\left\{y^{\mathrm{L}}, \mathrm{y}^{\mathrm{L}}\right\}$ : Both projects realize $\mathrm{y}^{\mathrm{L}}$; this occurs with probability $(1-\mathrm{e})^{2}$. One of the $\mathrm{y}^{\mathrm{L}}$ projects is allocated to the SPV and the bank retains the other on-balance sheet. Neither the bank nor the SPV can honor its debt.

In the previous section the SPV failed in two states of the world, the two situations where it realized $\mathrm{y}^{\mathrm{L}}$. Now, the SPV fails in three states of the world, due to the strategic adverse selection problem. Only if $\left\{\mathrm{y}^{\mathrm{H}}, \mathrm{y}^{\mathrm{H}}\right\}$ is realized will the SPV be solvent. So, the expected income of the SPV is: $\mathrm{e}^{2} \mathrm{y}^{\mathrm{H}}+\left[2 \mathrm{e}(1-\mathrm{e})+(1-\mathrm{e})^{2}\right] \mathrm{y}^{\mathrm{L}}=\mathrm{e}^{2} \mathrm{y}^{\mathrm{H}}+\left(1-\mathrm{e}^{2}\right) \mathrm{y}^{\mathrm{L}}$. But this is less than 0.5D, by A6. Consequently, no investor will lend to the SPV. Recognizing this problem, the bank would like to commit to not engage in strategic adverse selection; the bank would like to commit to allocate projects prior to the realization of the project outcome. But there is no way to do this because project quality is not verifiable. 
Imagine for a moment that the bank could commit to subsidize the SPV in the event that the SPV realized $\mathrm{y}^{\mathrm{L}}$ and the bank realized $\mathrm{y}^{\mathrm{H}}$. Shortly, we will make clear what "subsidize" means. Let $\mathrm{F}^{\mathrm{SC}}$ be the face value of the debt issued by the SPV under commitment (and $\mathrm{F}^{\mathrm{C}}$ the corresponding face value of the debt issued by the bank). Then at the end of the period, the possible outcomes would be as follows:

- $\left\{y^{\mathrm{H}}, \mathrm{y}^{\mathrm{H}}\right\}$ : Both projects realize $\mathrm{y}^{\mathrm{H}}$; this occurs with probability $\mathrm{e}^{2}$. Both on- and offbalance sheet debts can be repaid in full. The expected profit to the bank in this case is:

$$
\mathrm{e}^{2}\left[2 \mathrm{y}^{\mathrm{H}}-\mathrm{h}(\mathrm{e})-(1-\tau) \mathrm{F}^{\mathrm{C}}-\mathrm{F}^{\mathrm{SC}}\right] \text {. }
$$

- $\quad\left\{\mathrm{y}^{\mathrm{H}}, \mathrm{y}^{\mathrm{L}}\right\}$ : The bank's project is worth $\mathrm{y}^{\mathrm{H}}$ and the SPV's is worth $\mathrm{y}^{\mathrm{L}}$. This occurs with probability e(1-e). The bank is solvent and subsidizes the SPV, so that neither defaults on its debt. "Subsidize" means that the bank assumes responsibility for the debt of the SPV. The bank's expected profit in this state of the world is:

$$
e(1-e)\left[y^{H}+y^{L}-h(e)-(1-\tau) F^{C}-F^{S C}\right] \text {. }
$$

- $\left\{y^{\mathrm{L}}, \mathrm{y}^{\mathrm{H}}\right\}$ : The bank's project is worth $\mathrm{y}^{\mathrm{L}}$ and the SPV's is worth $\mathrm{y}^{\mathrm{H}}$. This occurs with probability e(1-e). The SPV is solvent. Without the return on its SPV equity the bank would be insolvent. But the SPV has done well so that neither defaults on its debt. The expected profit in this case is the same as in the previous case, though the interpretation is different:

$$
e(1-e)\left[y^{\mathrm{H}}+y^{\mathrm{L}}-\mathrm{h}(e)-(1-\tau) \mathrm{F}^{\mathrm{C}}-\mathrm{F}^{\mathrm{SC}}\right]
$$

- $\quad\left\{y^{\mathrm{L}}, \mathrm{y}^{\mathrm{L}}\right\}$ : Both projects realize $\mathrm{y}^{\mathrm{L}}$; this occurs with probability $(1-\mathrm{e})^{2}$. Neither the bank nor the SPV can honor its debt. The bank earns zero.

With this commitment, the bank's problem is to choose $\mathrm{F}^{\mathrm{C}}, \mathrm{F}^{\mathrm{SC}}$, and $\mathrm{e} \in\left\{\mathrm{e}_{\mathrm{H}}, \mathrm{e}_{\mathrm{L}}\right\}$ to:

$$
\max V^{C}=e^{2}\left[2 y^{H}-h(e)-(1-\tau) F^{C}-F^{S C}\right]+2 e(1-e)\left[y^{H}+y^{L}-h(e)-(1-\tau) F^{C}-F^{S C}\right]
$$
s.t.
(i) $\mathrm{E}\left[\mathrm{F}^{\mathrm{C}}\right] \geq 0.5 \mathrm{D}$
(Participation of Bank Investors) 
(ii) $\mathrm{E}\left[\mathrm{F}^{\mathrm{SC}}\right] \geq 0.5 \mathrm{D} \quad$ (Participation of SPV Investors)

(iii) $\mathrm{V}^{\mathrm{C}}\left(\mathrm{e}=\mathrm{e}_{\mathrm{H}} ; \mathrm{e}_{0}=\mathrm{e}_{\mathrm{H}}\right) \geq \mathrm{V}^{\mathrm{C}}\left(\mathrm{e}=\mathrm{e}_{\mathrm{L}} ; \mathrm{e}_{0}=\mathrm{e}_{\mathrm{H}}\right) \quad$ (Incentive Compatibility)

Constraints (i) and (ii) can be re-written, respectively, as:

$$
e(2-e) F^{C}+(1-e)^{2}\left[y^{L}(1-c)-h(e)\right] \geq 0.5 D,
$$

and

$$
e(2-e) F^{S C}+(1-e)^{2} y^{L} \geq 0.5 D
$$

We proceed as above and suppose lenders' beliefs are $\mathrm{e}_{0}$. Then lenders will participate in lending to the bank and the SPV, respectively, if the promised repayments are at least:

$$
\mathrm{F}_{0}^{\mathrm{C}}=\frac{0.5 \mathrm{D}-\left(1-\mathrm{e}_{0}\right)^{2}\left[\mathrm{y}^{\mathrm{L}}(1-\mathrm{c})-\mathrm{h}\left(\mathrm{e}_{0}\right)\right.}{\mathrm{e}_{0}\left(2-\mathrm{e}_{0}\right)}
$$

and

$$
F_{0}^{S C}=\frac{0.5 D-\left(1-e_{0}\right)^{2} y^{L}}{e_{0}\left(2-e_{0}\right)}
$$

Suppose that beliefs are consistent, i.e., $\mathrm{e}=\mathrm{e}_{0}=\mathrm{e}_{\mathrm{H}}$. Then:

$$
\begin{aligned}
V^{C}=2 e_{H} y^{H} & +2 e_{H}\left(1-e_{H}\right) y^{L}-e_{H}\left(2-e_{H}\right) h\left(e_{H}\right)-(1-\tau)\left[0.5 D-\left(1-e_{H}\right)^{2}\left[y^{L}(1-c)-h\left(e_{H}\right)\right]\right. \\
- & {\left[0.5 D-\left(1-e_{H}\right)^{2} y^{L}\right] }
\end{aligned}
$$

Lemma 3: If

$$
\begin{gathered}
2 y^{H}\left(e_{H}-e_{L}\right)+2 y^{L}\left[e_{H}\left(1-e_{H}\right)-e_{L}\left(1-e_{L}\right)\right]-h\left(e_{H}\right) e_{H}\left(2-e_{H}\right)+h\left(e_{L}\right) e_{L}\left(2-e_{L}\right) \\
-(1-\tau)\left[0.5 D-\left(1-e_{H}\right)^{2}\left[y^{L}(1-c)-h\left(e_{H}\right)\right]\left[1-\frac{e_{L}\left(2-e_{L}\right)}{e_{H}\left(2-e_{H}\right)}\right]-\left[0.5 D-\left(1-e_{H}\right)^{2} y^{L}\right]\left[1-\frac{e_{L}\left(2-e_{L}\right)}{e_{H}\left(2-e_{H}\right)}\right]>0\right.
\end{gathered}
$$


then at the optimum, lenders believe $\mathrm{e}_{0}=\mathrm{e}_{\mathrm{H}}$ and the bank chooses $\mathrm{e}=\mathrm{e}_{\mathrm{H}}$. The value of the bank is given by (3).

Proof: The incentive compatibility constraint, $V^{C}\left(e=e_{H} ; e_{0}=e_{H}\right) \geq V^{C}\left(e=e_{L} ; e_{0}=e_{H}\right)$, is satisfied if the condition in the lemma holds. //

Proposition 2: If the bank can commit to subsidize the SPV, then the profitability of the bank is the same as it would be when projects were allocated between the bank and the SPV prior to their realizations, i.e., when there was no strategic adverse selection.

Proof: It may be verified that $\mathrm{V}^{\mathrm{S}}=\mathrm{V}^{\mathrm{C}}$. //

Intuitively, while the debt is repriced to reflect the subsidy from the bank in the state $\left\{\mathrm{y}^{\mathrm{H}}, \mathrm{y}^{\mathrm{L}}\right\}$, there are no effects involving the bankruptcy cost or taxes. Consequently, the bank's value is the same as when projects were allocated between the bank and the SPV prior to their realizations.

Proposition 2 states that securitization would be feasible, i.e., investors would lend to the SPV, and it would be profitable for the bank (under the conditions stated in Proposition 1), if it were possible to overcome the problem of strategic adverse selection by the bank committing to subsidize the SPV. However, accounting and regulatory rules prohibit such a commitment, even if it were possible. That is, a formal contract, which can be upheld in court and which is consistent with accounting and regulatory rules, effectively would not be consistent with the SPV being a QSPV, and hence the debt would not be off-balance sheet. The bankruptcy costs would not be minimized. We now turn to the issue of whether a commitment is implicitly possible in a repeated context.

\section{F. The Repeated SPV Game: The Implicit Recourse Equilibrium}

In any single period, the bank cannot securitize a project because lenders will not lend to the SPV due to the strategic adverse selection problem. We now consider an infinite repetition of the one period problem, where for simplicity we assume that the bank has exactly $\$ \mathrm{E}$ available every 
period to finance the two projects. ${ }^{24}$ The one-shot-game outcome of no securitization can be infinitely repeated, so this is an equilibrium of the repeated game. However, the idea that repetition can expand the set of equilibria, when commitment is possible, is familiar from the work of Friedman (1971), Green and Porter (1984), and Rotemberg and Saloner (1986), among others. The usual context is oligopolistic competition, where the competing firms are incompletely informed about their rivals' decisions. The firms want to collude to maintain oligopolistic profits, but cannot formally commit to do so. Here the context is somewhat different. The sponsoring bank and the investors in the SPV "collude" in adopting a contractual mechanism that cannot be written down because of accounting and regulatory rules. In a sense the two parties are colluding against the accountants and regulators. We will call such an equilibrium an "Implicit Recourse Equilibrium."

For this section we will suppose that the interest rate, $r$, is positive and constant. This means that everywhere there was a " $\mathrm{D}$ " above, it must be replaced by $(1+\mathrm{r}) \mathrm{D}$, as the risk neutral investors require that they earn an expected rate of return of $r$.

The basic idea of repeating the SPV game is as follows. Suppose investors believe that the bank will subsidize the SPV in the state $\left\{\mathrm{y}^{\mathrm{H}}, \mathrm{y}^{\mathrm{L}}\right\}$, when the SPV would otherwise default. I.e., investors have priced the debt as $\mathrm{F}^{\mathrm{C}}$ and $\mathrm{F}^{\mathrm{SC}}$, as given above, and their beliefs are $\mathrm{e}_{0}=\mathrm{e}_{\mathrm{H}}$. Now, suppose that the state $\left\{\mathrm{y}^{\mathrm{H}}, \mathrm{y}^{\mathrm{L}}\right\}$ occurs, that is, the state of the world where the bank is supposed to subsidize the SPV. The realized bank profit is supposed to be:

$$
y^{\mathrm{H}}+\mathrm{y}^{\mathrm{L}}-\mathrm{h}\left(\mathrm{e}_{\mathrm{H}}\right)-(1-\tau) \mathrm{F}^{\mathrm{C}}-\mathrm{F}^{\mathrm{SC}} \text {. }
$$

But, suppose the bank reneges and leaves the SPV bankrupt with $\mathrm{y}^{\mathrm{L}}-\mathrm{F}^{\mathrm{SC}}<0$, i.e., there is no subsidy. The SPV then defaults on its debt. Then, in that case, on-balance sheet the bank realizes:

$$
y^{\mathrm{H}}-\mathrm{h}\left(\mathrm{e}_{\mathrm{H}}\right)-(1-\tau) \mathrm{F}^{\mathrm{C}} .
$$

\footnotetext{
${ }^{24}$ In other words, we assume that if the bank does well it pays a dividend such that $\mathrm{E}$ remains as the equity in the bank. If the bank does poorly, we assume that the bank can obtain more equity so that again there is E. Obviously, this omits some interesting dynamics about the bank's capital ratio and begs the question of the coexistence of outside equity and debt. These issues are beyond the scope of this paper.
} 
So, the one-shot gain from reneging on the implicit contract is $\mathrm{F}^{\mathrm{SC}}-\mathrm{y}^{\mathrm{L}}>0$. Since this is positive, the bank has an incentive to renege. But, in a repeated setting, investors can punish the bank by not investing in the bank's SPV in the future, say for N periods. If the bank cannot securitize again for $\mathrm{N}$ periods, it loses (from Proposition 1):

$\sum_{t=1}^{N} \delta^{t}\left(V^{S}-V^{H}\right)=\sum_{t=1}^{N} \delta^{t}\left[\left(1-e_{H}\right)^{2} y^{L} c-\tau c\left(1-e_{H}\right)^{2} y^{L}-\tau\left[0.5 D-\left(1-e_{H}\right)^{2} y^{L}\right]\right]$

where $\delta$ is the discount rate. Obviously, the bank will not renege on subsidizing the SPV if the expected present value of the loss is greater than the one-shot gain to deviating. There are combinations of $\mathrm{N}$ and $\delta$ that will support the Implicit Recourse Equilibrium. While this is the intuition for Implicit Recourse Equilibrium, it clearly depends on the beliefs of the investors and the bank. There may be many such equilibria, with very complicated, history dependent, punishment strategies.

The idea is for the investors in the SPV to enforce support when needed by the threat of refusing to invest in SPV debt in the future if the sponsoring firm deviates from the implicit contract. This means that there is a "punishment period" where investors refuse to invest in SPV debt if the sponsor has not supported the SPV in the past. In general, strategies can be path dependent in complicated ways (See Abreu (1988)). However, a simple approach is to restrict attention to punishments involving playing the no-SPV stage game equilibrium for some period of time, starting the period after a deviation has been detected. We adopt this approach and assume investor and bank beliefs are consistent with this.

For simplicity we will construct a simple example of an Implicit Recourse Equilibrium. Assume that all agents discount at the rate $\mathrm{r}$, and consider the case where $\mathrm{N}=\infty$. This corresponds to a "punishment period" of forever. ${ }^{25}$ At the start of each period the game proceeds as follows:

1. The bank and the SPV offer debt in the capital markets to investors with face values of $\mathrm{F}^{\mathrm{C}}$ and $\mathrm{F}^{\mathrm{SC}}$, respectively.

2. Investors choose which type of debt, and how much, to buy.

\footnotetext{
${ }^{25} \mathrm{We}$ do not claim that this is the optimal punishment period.
} 
If investors purchase the SPV debt, then off-balance sheet financing proceeds. Otherwise the bank finances both projects on-balance sheet.

At the end of a period, the state of the world is observed, but cannot be verified. If the state of the world is $\left\{\mathrm{y}^{\mathrm{H}}, \mathrm{y}^{\mathrm{L}}\right\}$, i.e., the on-balance sheet project returns $\mathrm{y}^{\mathrm{H}}$ while the off-balance sheet project returns $\mathrm{y}^{\mathrm{L}}$, then the bank is supposed to subsidize the SPV, as described above. At the start of any period, both the banks and investors know all the previous outcomes.

Consider the following trigger strategy based on investor and bank beliefs: If the bank ever does not subsidize the SPV when the state of the world is $\left\{\mathrm{y}^{\mathrm{H}}, \mathrm{y}^{\mathrm{L}}\right\}$, then investors never again invest in the SPV because they believe that the sponsor will not support it and hence the promised interest rate, corresponding to $\mathrm{F}^{\mathrm{SC}}$, is too low. The bank believes that if it deviates investors will never again buy its SPV's debt in the market. Then a subgame perfect Nash equilibrium exists under certain conditions:

Proposition 3 (Existence of the Implicit Recourse Equilibrium): If there exists an interest rate, $0 \leq \mathrm{r} \leq 1$, such that the following quadratic inequality is satisfied,

$$
\begin{aligned}
& 0.5 D r^{2}+r\left\{0.5 D\left[1-\tau e_{H}\left(2-e_{H}\right)\right]+\left(1-e_{H}\right)^{2} h\left(e_{H}\right)+y^{L} B\right\}-0.5 D \tau e_{H}\left(2-e_{H}\right)+y^{L} A>0 \\
& \text { where } A \equiv\left[\left(1-e_{H}\right)^{2}(c+\tau(1-c)) e_{H}\left(2-e_{H}\right)-\tau\left(1-e_{H}\right)^{2} c e_{H}\left(2-e_{H}\right)\right] \\
& \text { and } B \equiv\left[\left(1-e_{H}\right)^{2}(1-c)-e_{H}\left(2-e_{H}\right)\right]
\end{aligned}
$$

then securitization is feasible and optimal for any bank that would choose securitization were it able to commit to the policy of subsidization.

Proof: Consider a bank that would choose securitization were it able to commit to subsidize its SPV in the state $\left\{y^{\mathrm{H}}, \mathrm{y}^{\mathrm{L}}\right\}$. Also, consider a date at which the bank has always subsidized its SPV in the past. Over the next period the bank is worth $\mathrm{V}^{\mathrm{SC}}$ if it securitizes one project off-balance sheet and retains the other on balance sheet. If both projects are financed on-balance sheet, the bank is worth $\mathrm{V}^{\mathrm{H}}$. By Propositions 1 and $2, \mathrm{~V}^{\mathrm{C}}>\mathrm{V}^{\mathrm{H}}$. The present value of this difference is the benefit to the bank of being able to utilize off-balance sheet financing, assuming that it continues 
to subsidize its SPV in the state $\left\{\mathrm{y}^{\mathrm{H}}, \mathrm{y}^{\mathrm{L}}\right\}$. Over the infinite horizon this annuity value is: $\left(\mathrm{V}^{\mathrm{C}}-\right.$ $\left.\mathrm{V}^{\mathrm{H}}\right) /$ r. (Recall that agents discount at rate r.)

At the end of the period, suppose that the state of the world is, in fact, $\left\{y^{\mathrm{H}}, \mathrm{y}^{\mathrm{L}}\right\}$. Consider a oneshot deviation by the bank. That is, the bank decides not to subsidize the SPV, when investors expect the bank to subsidize it. From the expressions given above, the benefit to the bank of such a deviation is:

$$
y^{H}-h\left(e_{H}\right)-(1-\tau) F^{C}>y^{H}+y^{L}-h\left(e_{H}\right)-(1-c) F^{C}-F^{S C}
$$

which reduces to: $\mathrm{F}^{\mathrm{SC}}-\mathrm{y}^{\mathrm{L}}$.

To decide whether to deviate or not the bank compares the costs and benefits of deviation and chooses to subsidize the SPV as long as:

$$
\frac{\left(V^{C}-V^{H}\right)}{r}>F^{S C}-y^{L} .
$$

Substituting in this equation for $\mathrm{V}^{\mathrm{C}}, \mathrm{V}^{\mathrm{H}}$, and $\mathrm{F}^{\mathrm{SC}}$ and simplifying (after some algebra) gives the quadratic inequality in the proposition. //

Obviously, other equilibria could exist. But, the point is that there can exist equilibria where the costs of bankruptcy are avoided by using off-balance sheet financing.

\section{G. Summary and Empirical Implications}

The conclusion of the above analysis is that the value of SPVs lies in their ability to minimize expected bankruptcy costs; securitization arises to avoid bankruptcy costs. By financing the firm in pieces, control rights to the business decisions are separated from the financing decisions. The sponsor maintains control over the business while the financing is done via SPVs that are passive, that is, there are no control rights associated with the SPVs' assets. Bankruptcy is a process of transferring control rights over corporate assets. Off-balance sheet financing reduces the amount of assets that are subject to this expensive and lengthy process. 
We have argued that the ability to finance off-balance sheet via the debt of SPVs is critically dependent on a relational, or implicit, contract between the SPV sponsor and investors. The relational contract depends upon repeated use of off-balance sheet financing. We showed that this repetition can lead to an equilibrium with implicit recourse. Such an equilibrium implements the outcome of the equilibrium with formal commitments, were such contracts possible. The comparative static properties of the Implicit Recourse Equilibrium are based on the result that the equilibrium outcomes of the Implicit Recourse Equilibrium are the same as the commitment equilibrium.

The idea of a relational contract supporting the feasibility of SPVs leads to our first set of empirical tests, namely, that the trigger strategy can only provide intertemporal incentives for the sponsor insofar as the sponsor exists. If the sponsor is so risky that there is a chance the sponsor will fail, and be unable to support the SPV, then investors will not purchase the SPV debt. We examine this idea by testing the proposition that investors, in pricing the debt of the SPV, care about the risk of the sponsor defaulting, above and beyond the risks of the SPV's assets.

The second hypothesis that we empirically investigate is suggested by Corollary 1 . Because the Implicit Recourse Equilibrium implements the outcome with formal commitment, Corollary 1 also describes the repeated equilibrium with implicit recourse. Corollary 1 says that the profitability of off-balance sheet financing is increasing in the bankruptcy cost, c, and increasing in the riskiness of the project (i.e., the chance of bankruptcy), (1- $\left.\mathrm{e}_{\mathrm{H}}\right)$. In other words, riskier sponsors should securitize more, ceteris paribus. Bankruptcy costs are not observable, but the riskiness of the firm can be proxied for by its firm bond rating.

\section{Data}

The rest of the paper examines some evidence that is supportive of our model. Our analysis suggests that the risk of a sponsoring firm should, because of implicit recourse, affect the risk of the ABS that are issued by its SPVs. We measure the sponsor's risk by its bond rating, and focus on two ways that this risk might be manifested. As mentioned above, we first consider whether investors care about the strength of the sponsoring firm, above and beyond the characteristics of the ABS themselves. Second, we consider whether riskier firms are more likely to securitize in the first place. To these ends we utilize a number of datasets. 
To investigate our first topic, investors' sensitivity to the sponsor's strength, we obtained from Moody's a unique dataset describing every credit-card ABS issued between 1988:06 and 1999:05 that Moody's tracked. This covers essentially all credit-card ABS through mid 1999. The dataset includes a detailed summary of the structure of each ABS, including the size and maturity of each ABS tranche. It summarizes the credit enhancements behind each tranche, such as the existence of any letters of credit, cash collateral accounts, and reserve accounts. Moody's also calculated the amount of direct subordination behind each A and B tranche. ${ }^{26}$ These variables contain the information about the ABS structure that investors observed at the time of issuance. Further, the dataset includes some information about the asset collateral underlying each ABS, such as the age distribution of the credit-card accounts. Also included is the month-by-month ex post performance of each note, in particular the excess spread and its components like the chargeoff rate. The sample used below includes only the A and B tranches, i.e., the tranches that were sold publicly.

Although it is difficult to find pricing information on credit-card ABS, we obtained from Lehman Brothers a dataset containing the initial yields on a large subset of these bonds that were issued in 1997-1999, for both the A and B notes. We obtained similar data from Asset Sales Reports for bonds that were issued before 1997. We computed the initial spread as the initial yield minus one month LIBOR at the time of issuance. We also collected Moody's ratings from Bloomberg for the sponsors of each ABS in the Moody's dataset above, which are typically banks. We use the bank's senior unsecured bond rating at issuance. ${ }^{27}$

To investigate our second topic, an analysis of which banks securitize, we use the bank ('entity') level Call Report panel data that comes from the regulatory filings that banks file each quarter, from 1991:09 - 2000:06. Before 1996 we use only the third quarter (September) data, since credit card securitizations were reported only in the third quarter during that period. We also obtained from Moody's a large dataset of all of their ratings of banks' long-term senior obligations,

\footnotetext{
${ }^{26}$ E.g., the amount of subordination behind the A note is calculated as $(\mathrm{BalB}+\mathrm{BalC}) /(\mathrm{Bal} A+\mathrm{BalB}+\mathrm{BalC})$, where $\mathrm{BalX}$ is the size (the balance) of tranche $\mathrm{X}$ when it exists. The dataset provided the current amount of subordination using current balances. For our analysis below, we want the original amount of subordination at the time of issuance. We were able to estimate this given the original balance sizes of the $\mathrm{A}$ and $\mathrm{B}$ notes, as well as an estimate of the size of any $\mathrm{C}$ note. The size of $\mathrm{C}$ notes is not directly publicly available, but we backed out their current size from the reported current amount of subordination behind the B notes. We used this to estimate the original amount of subordination behind the A and B notes.
}

${ }^{27}$ We use the rating of the current owner of the ABS trust, accounting for any mergers and acquisitions. 
including an ID variable that allowed us to match this data to the Call Report ID variables. Accordingly our sample includes all the banks in the Call Report dataset for which we have a matching rating. ${ }^{28}$ This yields a sample of almost 400 banks and over 5000 bank-quarters, which is large relative to the samples analyzed in previous related literature.

\section{Empirical Tests: Are there Implicit Recourse Commitments?}

In this section we analyze the determinants of the spread on the notes issued by the SPV to the capital markets. Borgman and Flannery (1997) also analyze asset-backed security spreads, over the period 1990-1995. They find that credit card ABS require a lower market spread if the sponsoring firm is a bank or if the sponsor includes guarantees as a form of credit enhancement.

The unit of observation is a transaction, that is a note issuance, either the A note or the B note. We examine the cross sectional determinants of the spreads. The spreads provide us with investors' assessment of the risk factors behind each note. All the A notes were on issuance rated AAA by Moody's. ${ }^{29}$ If these ratings are sufficient statistics for default, then the probability of default should be the same for all the A notes and in the simplest case (e.g., if there is no implicit recourse) presumably investors would pay the same initial price for them. As discussed above, to test for the existence of a relational contract allowing for recourse, we examine whether other factors affect the ratings of the notes, in particular whether the strength of the sponsor matters, as estimated by its senior unsecured credit rating at the time of issuance. Specifically, we estimate equations of the following form:

$$
\text { Spread }_{i, j, k, t}=\beta_{0}{ }^{\prime} \text { Time }_{t}+\beta_{1}{ }^{\prime} \text { Structure }_{i}+\beta_{2} \text { 'Assets }_{i}+\beta_{3} \text { ' }^{\prime} \text { rust }_{j}+\beta_{4}{ }^{\prime} \text { Rating }_{k, t}+\varepsilon_{i, j, k, t},
$$

where $\operatorname{Spread}_{\mathrm{i}, \mathrm{j}, \mathrm{k}, \mathrm{t}}$ is the initial spread (net of one month LIBOR) on note $i$ from trust $j$ and sponsor $k$ at the time $t$ of issuance. Time is a vector of year dummies that control for time varying risk premia as well as all other macroeconomic factors, including the tremendous growth in the ABS market over the sample period. Structure $\mathrm{i}_{\mathrm{i}}$ represents the structure of tranche $i$ at the time of issuance, such as the degree of subordination and other credit enhancements supporting it, and

\footnotetext{
${ }^{28}$ Since small banks are less likely to be rated, matches are most common for the larger banks.

${ }^{29}$ All but two of the B notes were initially rated A; the two exceptions were rated AA. By distinguishing the A- and B-notes, the analysis implicitly controls for any clientele effects.
} 
Assets $_{\mathrm{i}}$ represents the quality of the credit-card assets underlying the tranche at that time. Trust $_{\mathrm{j}}$ is a vector of trust dummies. Rating $_{\mathrm{k}, \mathrm{t}}$ is the senior unsecured bond rating of the sponsor $k$ of the notes' trust at the time of issuance. The trust dummies control for all trust fixed effects. Since many sponsors have multiple trusts, the dummies also essentially control for sponsor fixed effects. ${ }^{30}$ Given this, the ratings variable will essentially capture the effect of changes in a sponsor's rating over time.

Our initial sample includes only the A notes, but later we add the B notes, with Structure then including an indicator for the B notes (Junior). Table 2 presents summary statistics for the key variables used in the analysis, for the sample of A notes. The sample runs from 1988-1999. Over that time the average A-note spread was just under 50 basis points (b.p.), with a relatively large standard deviation of 68 b.p. About half of the sponsors have ratings of single A (RatingA) on their senior unsecured debt, with the rest being about equally likely to have ratings of $\mathrm{AA}$ (RatingAA) or ratings of $\mathrm{Baa}$ and $\mathrm{Ba}$ (RatingB).

\section{A. Analysis of the A-Note Spreads}

Table 3 shows the results for the A notes. Column (1) includes only the year dummies (omitting $1988^{31}$ ) and the sponsor ratings (as well as the trust fixed effects). Nonetheless, the adjusted $\mathrm{R}^{2}$ is already relatively large. The year dummies are significant, with spreads peaking in the early 1990s, perhaps due to the recession. The sponsor ratings at the bottom of the table are of primary interest. Relative to the omitted AA-rated sponsors, the effects of riskier sponsor ratings is positive and monotonic. The coefficient RatingB for the riskiest ( $\mathrm{Baa}$ and $\mathrm{Ba}$ ) sponsors is statistically significant. Thus investors do indeed require higher yields for bonds issued by the trusts of riskier sponsors. That is, even though the A notes all have the same bond ratings, the strength of the sponsor also matters, consistent with our model. This effect is also economically significant. The riskiest sponsors must pay an additional 46 b.p. on average, which is about the same size as the average A-note spread and sizable relative to the standard deviation of spreads in Table 2. This is a relatively strong result given the trust dummies which control for all average and time-invariant effects. The variation in a sponsor's rating over time is sufficient to cause significant changes over time in the yields paid by its ABS.

\footnotetext{
${ }^{30}$ Though a given trust can also have multiple owners over time, e.g. after a merger or acquisition.

${ }^{31}$ Because of missing values in some of the covariates, some of the time dummies drop out of the regressions.
} 
This result could be interpreted as suggesting that, even if the rating agencies place some weight on the risk of a sponsor in assessing the risk of their ABS notes, they do not do so fully. But the bond ratings are discretized, not continuous-valued, so there can be some differences in risk even among bonds with the same ratings. Also, investors' views of the risk might not completely coincide with the views of the ratings agencies. Hence we also directly control for the potential risk factors observable by investors. The next columns start by adding controls for the structure of the A notes. Of course, this structure is endogenous (but predetermined by the time of issuance) and should itself reflect the rating agencies' view of the notes' risk. Recall that the trust dummies already controlled for all time-invariant trust effects. These dummies are always jointly significant (unreported). For instance, some trusts might get locked into an older trust-structure technology that is considered riskier.

Column (2) explicitly controls for the amount of direct subordination behind each A note. LowSub represents the quartile of notes with the smallest amount of subordination (i.e., the riskiest notes as measured by the relative size of their 'buffer', ceteris paribus). It has a significant positive coefficient. Thus, the notes with less enhancement have to offer investors higher yields to compensate. Nonetheless, the coefficients on the ratings variables change very little. ${ }^{32}$ Column (3) adds as a control the expected maturity of the notes (Maturity). It also adds the size of the sellers' interest (SellersInt) and a dummy variable for whether the note is fixed rate or not (FixedRt). The results indicate that longer maturity and fixed-rate notes pay significantly higher spreads. ${ }^{33}$ Given these controls the subordination measure (LowSub) becomes insignificant. This could mean that the size of the subordination might be a function of, among other things, maturity and whether the deal is fixed rate. Despite these effects, again the coefficients on the ratings do not change much. Column (4) controls for additional credit enhancement features, specifically dummy variables for the presence of a cash collateral account (I_CCA), a letter of credit (I_LOC), an internal reserve fund (I_RES), or other enhancement (I_Other). Given the other covariates, these additional enhancements are individually and jointly insignificant. (Though as indicated in Table 2, only CCAs are frequently used.) But the sponsor ratings remain significant.

\footnotetext{
32 Since LowSub is often missing, the sample size is smaller than in column (1). Nonetheless our conclusions below persist under the larger sample available if we do not control for LowSub.

${ }^{33}$ Moody's (1995) noted a similar effect of maturity on spreads through 1993.
} 
Finally, column (5) includes measures of the riskiness of the underlying portfolio of credit card receivables. Again, these are variables that the rating agencies take into account when approving the bond structure with a given rating, so their effects could already have been taken into account. The variable "Seasoned" is an indicator for older portfolios, with an average account age above 24 months. Since older accounts tend to have lower probabilities of default, this should reflect a safer portfolio. ${ }^{34}$ Chargeoff is the initial (ex post) chargeoff rate in the portfolio. ${ }^{35}$ Both variables are statistically significant, with the intuitive signs. Riskier portfolios, whether unseasoned or with higher charge-off rates, must pay higher spreads. While Chargeoff is an ex post chargeoff rate, the conclusions are the same on instrumenting for it using the balance-weighted average chargeoff rate in the trust from the month before the issuance of each note in the sample. Even with these controls, the sponsor's rating remains significant. ${ }^{36}$

\section{B. Analysis of the A-Note and B-Note Spreads}

Table 4 repeats this analysis using both the A and B notes. All regressions now include an indicator variable (Junior) for the B notes. In column (1), this indicator is significantly positive, as expected given the greater risk of the B notes. They must pay on average 29 b.p. more than the A notes. The coefficient on the riskiest sponsors, RatingB, remains significant and large at 42 b.p. Thus the extra yield that must be paid by risky sponsors is even larger than the extra yield that must be paid by B notes. In column (2), LowSub indicates the A notes with the lowest quartile of subordination, and LowSubJr indicates the B notes with the lowest quartile of subordination. The latter variable is significant (and drives out the direct effect of the Junior indicator), implying that

\footnotetext{
${ }^{34}$ For an account-level analysis of the determinants of default probabilities, see e.g. Gross and Souleles (2002). For a portfolio-level analysis, see Musto and Souleles (2004). The original age data reflects the age of the accounts across the entire trust as of a given time. To estimate the age distribution of accounts underlying a given note at the time of issuance, we subtracted the time since closing. This assumes that the composition of the assets did not change too much between the time of closing and the time of reporting.

${ }^{35}$ We take it from month three after issuance, since the excess spread components are sometimes missing in months one and two.

${ }^{36} \mathrm{We}$ also tried various extensions. For instance, we controlled for the importance of (on-balance sheet) credit card balances and other consumer receivables relative to total assets (CC/Assets). (When available from "Moody's Credit Opinions", CC/Assets is consumer receivables relative to assets. Otherwise, it is credit card balances relative to total assets from the Call Report data. In the latter case, in any given year CC/Assets is taken from the September quarter, and for 1988-90, it is taken from 1991:09.) CC/Assets had a significant negative effect on spreads, but did not change the results regarding the ratings. This suggests that the latter effect might not reflect just a correlation between the assets in the trust and the assets onbalance sheet, since presumably the credit card assets in the trust are more highly correlated with the credit card assets on-balance sheet, compared to other on-balance sheet assets.
} 
B notes with less enhancement must pay higher yields. The rest of the analysis is analogous to that in Table 3, and the conclusions are the same.

Overall, the estimated effects of the sponsors' ratings appear to be robust. Even controlling for the ABS structure and underlying assets, the ratings of the sponsors remain significant, both statistically and economically. This supports our theoretical conclusion that the strength of the sponsor matters, because of the possibility of implicit recourse commitment. To reiterate, the trigger strategy at the root of the relational contract concerning recourse requires that the sponsor exist, that is, have not defaulted. The results are consistent with the investors in the ABS markets pricing the risk that the sponsor disappears and cannot support its SPVs.

\section{Empirical Tests: Which Firms Securitize?}

In this section we turn to testing whether riskier firms securitize more than others. Since our model is of course highly stylized we analyze more generally the determinants of securitization. We estimate equations of the following form, using the Call Report panel data from quarters 1991:09 - 2000:06:

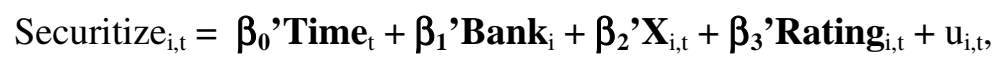

where Securitize $\mathrm{i}_{\mathrm{i}, \mathrm{t}}$ reflects the extent of credit-card securitization by bank $i$ at time $t$, measured in one of three ways: i) We start with logit models of the probability that bank $i$ has securitized, with dependent variable I_Sec being an indicator for whether the bank has any securitized credit card loans outstanding at time $t$ (the extensive margin). ii) We also estimate Tobit models where the dependent variable Sec/Assets measures the amount of these securitizations normalized by total bank assets (including the securitized loans). ${ }^{37}$ iii) To distinguish the intensive margin component in ii) from the extensive margin in i), we also estimate conditional OLS models of Sec/Assets conditional on Sec/Assets $>0{ }^{38}$

\footnotetext{
${ }^{37} \mathrm{We}$ include the securitized loans in assets in the denominator for convenience in interpreting Sec/Assets as a fraction $\leq 1$. The denominator can also be interpreted as managed assets, although we do not have information on the full extent of off-balance sheet assets (including non-credit card assets) under management. Our conclusions are similar on not including the securitized loans in the denominator.

${ }^{38}$ We would also like to estimate selection models, but we lack persuasive omitted instruments.
} 
The dependent variables again include a full set of time dummies, this time quarter dummies. $\mathbf{X}_{\mathrm{i}, \mathrm{t}}$ controls for various bank characteristics over time. In particular it includes cubic polynomials in bank $i$ 's total assets, Assets $\mathrm{i}_{\mathrm{i}, \mathrm{t}}$, and in its share of credit card balances in total assets, CC/Assets $\mathrm{i}_{\mathrm{i}, \mathrm{t}}$. These control for scale effects, including costs that might arise in setting up and maintaining securitization trusts. We also control for the bank's capital ratio (equity capital divided by assets), CapRatio $_{i, t}$, again using a cubic polynomial. ${ }^{39}$ Some specifications also control for all average and time-invariant bank effects $\left(\mathbf{B a n k}_{\mathrm{i}}\right)$, using the corresponding fixed effects estimator. $\mathbf{R a t i n g}_{\mathrm{i}, \mathrm{t}}$ is the Moody's rating of a bank's long-term senior obligations. Given the bank effects, the ratings variable will capture only within-bank variation, i.e., the effect of changes in a bank's rating over time on its propensity to securitize. ${ }^{40}$

Table 5 presents summary statistics for the key variables, for the entire sample period 1991-2000. To highlight the changes in the credit card ABS market over time, the second panel shows the same statistics for the end of the sample period (the first half of 2000). Comparing the panels shows the large growth in the market over the period. The fraction of banks that securitized (I_Sec) increased from about $8 \%$ in the early-to-mid 1990 s to $15 \%$ at the end of the sample period, averaging about $11 \%$ overall during the period. The magnitude of securitizations relative to assets (Sec/Assets) increased from about $1.6 \%$ to $4.1 \%$ over the sample period, averaging $3.3 \%$. The average bank rating declined over the sample period, though this happened for both the banks that securitized and those that did not.

Further, at any given time there is substantial cross-sectional variation across banks in the incidence and amount of securitization and in their ratings. The raw data suggest potential scale effects, with the big securitizers often being the bigger banks. These include highly rated securitizers, such as Citibank NV with an AA rating and Sec/Assets averaging about $71 \%$. By contrast firms like Advanta (Sec/Assets $\approx 70 \%$ ), Capital One $(\approx 57 \%)$, and Colonial $(\approx 65 \%)$ have lower ratings (RatingB). Given the potential problem of unobserved heterogeneity, our fixed

\footnotetext{
${ }^{39} \mathrm{We}$ did not include the securitized loans (Sec) in assets in the denominator of CC/Assets or CapRatio, in order to avoid creating spurious correlations between these variables and the dependent variables (I_Sec and Sec/Assets). Calomiris and Mason (2004) discuss the relation between securitization and capital ratios.

${ }^{40}$ The sample drops the few bank observations (about 10 banks) rated C and single B. Most of these were small banks in the early 1990s that did not securitize (only 1 of these banks securitized). As a result, they tended to be automatically dropped from the fixed effects estimation (or otherwise, their effect was imprecisely estimated due to their small sample size).
} 
effects estimators forego exploiting the purely cross-sectional average difference across banks; instead they set a high standard by relying on the more limited, but still substantial, within-bank variation over time in the incidence and amount of securitization and in the ratings. For instance, many banks were downgraded or upgraded at various times. Also, some banks securitized in only a few years (apparently just trying it out), whereas others securitized frequently but in varying amounts over time.

The main results are in Table 6. Column (1) begins with a logit model of the probability of securitizing (I_Sec), without bank effects. The effects of total assets (Assets), the importance of credit card assets (CC/Assets), and the capital ratio (CapRatio) are each jointly significant. Given the other covariates, in this specification the probability of securitizing is not monotonic in Assets; after initially increasing with Assets, it later declines. The probability of securitizing generally increases with $\mathrm{CC} /$ Assets (though declines a bit as CC/Assets gets very large). This could mean that having a large portfolio of credit cards provides economies of scale in securitizing. Also, the probability of securitizing is not monotonic in CapRatio (but increases for large CapRatio).

Of primary interest, at the bottom of the table, in this first specification the banks' ratings have a statistically significant, though non-monotonic, effect. Relative to the omitted AA ratings, the middle (RatingA) banks are somewhat less likely to securitize. Nonetheless, the riskiest (RatingB) are indeed much more likely to securitize.

Column (2) estimates a Tobit model of the amount of securitization (Sec/Assets). The conclusions are similar to those in the previous column. In both of these specifications, and those that follow, the pseudo and adjusted R2 statistics are relatively large.

The remaining columns control for bank fixed effects. Column (3) uses the fixed effects logit estimator. Note that as a result the sample size significantly declines, since this estimator drops banks for which I_Sec does not vary over time. Now the effect of Assets is monotonically increasing, though CC/Assets is less monotonic and CapRatio becomes insignificant. More importantly, both RatingA and RatingB have significant positive effects, with a larger effect for the latter. Thus these results suggest that the probability of securitizing does indeed increase monotonically with banks' riskiness, consistent with our model. Column (4) instead focuses on the intensive margin, estimating a conditional OLS model of the fraction of securitized assets conditional on Sec/Assets $>0$. CapRatio now has a monotonically increasing effect, though Assets 
has a negative effect on the intensive margin, and CC/Assets is not monotonic. While RatingA is positive but insignificant, RatingB has a larger positive coefficient, significant at the $6 \%$ level. Relative to banks with AA ratings, those with B ratings have about a 3.4 percentage point (p.p.) larger securitization fraction, on average. This is an economically significant effect, given that it is comparable in magnitude to the average Sec/Assets fraction of about 3.3 p.p.

Overall we conclude that there is some evidence that riskier firms are more likely to securitize, consistent with our model, though the effect is not always monotonic, depending on the specification. The effects of Assets, CC/Assets, and CapRatio are more sensitive to the specification. $^{41}$

\section{Summary}

The empirical results are consistent with the theory proposed above, namely that an implicit contractual relationship between SPV sponsors and capital markets investors reduces bankruptcy costs. Consistent with the prediction that in the Implicit Recourse Equilibrium investors would price the risk of the sponsor defaulting, and hence being unable to subsidize the SPV, we found that the risk of the sponsor (as measured by the sponsor's bond rating) was consistently significant. The prediction of the model that firms with high expected bankruptcy costs would be the largest users of off-balance sheet financing was also generally confirmed.

\section{Conclusion}

Off-balance sheet financing is a pervasive phenomenon. It allows sponsoring firms to finance themselves by separating control rights over assets from financing. The operating entity, that is, the sponsoring firm, maintains control rights over the assets that generate cash flows. The assets (projects) can be financed by selling the cash flows to an SPV that has no need for control rights, because the cash flows have already been generated. We have argued that this arrangement is efficient because there is no need to absorb dead-weight bankruptcy costs with respect to cash

\footnotetext{
${ }^{41} \mathrm{We}$ also tried various extensions. For instance, to see whether the ratings in turn might reflect the amount of securitization, we tried instrumenting for the ratings using lagged ratings. However it is not clear how long a lag would be best. At the extreme, we used the ratings from 1991:06, the quarter before the sample period starts. Given how small the credit card ABS market was at the time, it is unlikely that those ratings were significantly affected by securitization. The results were generally insignificant. This is not surprising, given the smaller sample size (since the 1991 ratings are not always available) and reduced amount of variation.
} 
flows that have already been generated. Bankruptcy is a process for transferring control of the corporate assets so that new cash flows can be efficiently generated. Off-balance sheet financing is about financing new projects by using cash flows already generated as collateral. We showed that the efficient use of off-balance sheet financing is facilitated by an implicit arrangement, or contractual relations, between sponsoring firms and investors. The empirical tests, utilizing credit card asset-backed securitization as a testing ground, confirmed this interpretation of the SPV phenomenon. 


\section{References}

Abreu, Dilip (1988), "On the Theory of Infinitely Repeated Games with Discounting," Econometrica 56, 383-396.

Ashman, Ian (2000), "Using Cayman Islands Special Purpose Vehicles," International Financial Law Review (April), 32-34.

Baker, George, Robert Gibbons, and Kevin Murphy (2002), "Relational Contracts and the Theory of the Firm," Quarterly Journal of Economics 117, 39-83.

Beatty, Anne, Philip Berger, and Joseph Magliolo (1995), "Motives for Forming Research and Development Financing Organizations," Journal of Accounting and Economics 19, 411442.

Borgman, Richard and Mark Flannery (1997), "Loan Securitization and Agency: The Value of Originator-Provided Credit Enhancement," University of Florida, School of Business, working paper.

Calomiris, Charles and Joseph Mason (2004), "Credit Card Securitization and Regulatory Arbitrage," Journal of Financial Services Research 26, 5-28.

Croke, Jim (2003), “New Developments in Asset-Backed Commercial Paper," unpublished paper.

Elmer, Peter (1999), "Conduits: Their Structure and Risk,” FDIC Banking Review 12, 27-40.

FitchIBCA (1999), "Implications of Securitization for Finance Companies," Financial Services Special Report, November 15, 1999.

FitchIBCA (2001), “Asset-Backed Commercial Paper Explained," Structured Finance (November $8,2001)$.

Friedman, James W. (1971), “A Non-cooperative Equilibrium for Supergames," Review of Economic Studies 38, 1-12.

Gorton, Gary and George Pennacchi (1995), "Banks and Loan Sales: Marketing Non-Marketable Assets," Journal of Monetary Economics 35(3), 389-411.

Gorton, Gary and George Pennacchi (1989) "Are Loan Sales Really Off-Balance Sheet?," Journal of Accounting, Auditing and Finance 4:2, 125-45.

Gorton, Gary and Andrew Winton (2003). "Financial Intermediation," in The Handbook of the Economics of Finance: Corporate Finance, edited by George Constantinides, Milton Harris, and Rene Stulz (Elsevier Science; 2003) (NBER Working Paper \# 8928).

Green, Edward and Robert H. Porter (1984), "Noncooperative Collusion under Imperfect Price Information," Econometrica 52, 87-100.

Gross, David and Nicholas S. Souleles (2002). "An Empirical Analysis of Personal Bankruptcy and Delinquency,” Review of Financial Studies, 15(1), 319-347. 
Henry, David, Heather Timmons, Steve Rosenbush, and Michael Arndt (2002), "Who else is hiding debt?," Business Week (January 28), 36-37.

Higgins, Eric and Joseph Mason (2004), "What is the Value of Recourse to Asset Backed Securities? A Study of Credit Card Bank ABS Rescues," Journal of Banking and Finance $28,857-874$.

Hodge, J.B. (1996), “The Use of Synthetic Leases to Finance Build-to-Suit Transactions," Real Estate Finance Journal 11, 17-21.

Hodge, J.B. (1998), "The Synthetic Lease: Off-Balance-Sheet Financing of the Acquisition of Real Property," Real Estate Finance Journal 14, 159-76.

Humphreys, Thomas and R.M. Kreistman (1995), Mortgage-Backed Securities including REMICs and Other Investment Vehicles (New York; Little, Brown).

Klee, Kenneth and Brendt Butler (2002), "Asset-Backed Securitization, Special Purpose Vehicles and Other Securitization Issues," Uniform Commercial Code Law Journal 35, 23-67.

Kramer, Andrea (2003), Financial Products: Taxation, Regulation and Design, 3 volumes (Aspen Publishers; New York City).

Langbein, John H. (1997), "The Secret Life of the Trust: The Trust as an Instrument of Commerce," Yale Law Journal 107, 165-189.

Lim, Steve, Steve Mann, and Vassil Mihov (2003), "Market Evaluation of Off-Balance Sheet Financing: You Can Run But You Can't Hide,” Texas Christian University, working paper.

Mills, Lillian and Kaye Newberry (2004), "Firms' Off-Balance Sheet Financing: Evidence from their Book-Tax Reporting Differences," University of Arizona working paper.

Moody's Investors Service (May 29, 2003), “Securitization in New Markets: Moody's Perspective: Europe, Africa and the Middle East," International Structured Finance, Special Report.

Moody's Investors Service (2002), "Securitization and its Effect on the Credit Strength of Companies: Moody's Perspective 1987-2002," Special Comments.

Moody's Investors Service (August 30, 2002), "Bullet Proof Structures Revisited: Bankruptcies and a Market Hangover Test Securitizations' Mettle," Special Report.

Moody's Investors Service (September 1997), "Alternative Financial Ratios for the Effects of Securitization," in "Securitization and its Effect on the Credit Strength of Companies: Moody's Perspective 1987-2002," Special Comments (2002).

Moody's Investors Service (January 1997), "The Costs and Benefits of Supporting 'Troubled' Asset-Backed Securities: Has the Balance Shifted?," in "Securitization and its Effect on the Credit Strength of Companies: Moody's Perspective 1987-2002," Special Comments (2002). 
Moody's Investors Service (May 1995), "Spread Thin: An Empirical Investigation of Yields on Credit Card Asset-Backed Securities," Special Report.

Moody's Investors Service (November 11, 1994), "The 'C' Tranches of Credit Card-Backed Securities: Credit Risks for Investors Vary," Structured Finance, Special Report.

Moody's Investors Service (April 1993), “Asset-Backed Commercial Paper: Understanding the Risks," Special Report.

Musto, David, and Nicholas S. Souleles (2004), "A Portfolio View of Consumer Credit", University of Pennsylvania working paper.

Office of the Comptroller of the Currency, Federal Deposit Insurance Corporation, Board of Governors of the Federal Reserve System, and the Office of Thrift Supervision (2002), "Interagency Guidance on Implicit Recourse in Asset Securitizations," (May 23, 2002).

Peaslee, J. and D. Nirenberg (2001), Federal Income Taxation of Securitization Transactions $\left(3^{\text {rd }}\right.$. ed.; Frank J. Fabozzi Associates).

Pfister, Benedicte (2000), "Whole Business Securitizations: A Unique Opportunity for UK Assets," International Structured Finance Special Report, Moody's Investors Service (October 19, 2000).

Rotemberg, Julio and Garth Saloner (1986), "A Supergame-Theoretic Model of Price Wars During Booms," American Economic Review 76, 390-407.

Schwarcz, Steven (2003a), Structured Finance, third edition (Practicing Law Institute; New York City).

Schwarcz, Steven (2003b), "Commercial Trusts as Business Organizations: Unraveling the Mystery," The Business Lawyer 58 (February), 559-585.

Shakespeare, Catherine (2003), "Do Managers use Securitization Volume and Fair Value Estimates to Hit Earnings Targets?," University of Michigan, School of Business, working paper.

Shakespeare, Catherine (2001), "Accounting for Asset Securitizations: Complex Fair Values and Earnings Management," University of Michigan, School of Business, working paper.

Shevlin, Terrence (1987), "Taxes and Off-Balance Sheet Financing: Research and Development Limited Partnerships," The Accounting Review 52, 480-509.

Sitkoff, Robert H. (2003), "Trust Law, Corporate Law, and Capital Market Efficiency," University of Michigan Law School, John M. Olin Center for Law \& Economics Working Paper No. 20.

Standard and Poor's (no date), Structured Finance: Credit Card Criteria.

Standard and Poor's (2002), U.S. Legal Criteria for "Recycled" Special Purpose Entities.

Standard and Poor's (April 2002), U.S. Legal Criteria for Structured Finance Transactions. 
Weidner, Donald (2000), "Synthetic Leases: Structure Finance, Financial Accounting and Tax Ownership," Florida State University, College of Law, Working Paper No. 06 (April 2000). 


\section{Appendix: Proofs}

Lemma 1 Completion: It remains to verify that the equilibrium $F$ derived under assumptions A3 and A4 is consistent. That is, we now restate assumptions A3 and A4 in terms of primitives. Recall A3 was stated as: $2 y^{L}-h(e)<F$. The equilibrium $F$ is given by:

$$
F=\frac{D-\left(1-e_{H}\right)^{2}\left[2 y^{L}(1-c)-h\left(e_{H}\right)\right]}{e_{H}\left(2-e_{H}\right)} .
$$

Substituting the expression for F into A3 and simplifying gives:

$$
2 y^{L}\left[1-c\left(1-e_{H}\right)^{2}\right]-h\left(e_{H}\right)<D
$$

which is A3 stated in terms of primitives and consistent with the equilibrium.

Recall A4 was stated as: $2 y^{\mathrm{H}}-\mathrm{h}(\mathrm{e})>\mathrm{y}^{\mathrm{H}}+\mathrm{y}^{\mathrm{L}}-\mathrm{h}(\mathrm{e})>\mathrm{F}$. Substitute the equilibrium value of $\mathrm{F}$ into $\mathrm{y}^{\mathrm{H}}+\mathrm{y}^{\mathrm{L}}-\mathrm{h}(\mathrm{e})>\mathrm{F}$, and simplify to obtain:

$$
\left(e_{H}-1\right)^{2} y^{L}(1-2 c)-h\left(e_{H}\right)>\text { D. // }
$$

Lemma 2 Completion: It remains to verify that the equilibrium $F^{B}$ and $F^{S}$ derived under $A 3 a$ and $\mathrm{A} 4 \mathrm{a}$ are consistent. That is, we now restate assumptions $\mathrm{A} 3 \mathrm{a}$ and $\mathrm{A} 4 \mathrm{a}$ in terms of primitives. Recall A3a: $2 y^{L}-h(e)<F^{B}+F^{S}$. The equilibrium $F^{B}$ and $F^{S}$ are given by:

$$
F^{B}=\frac{0.5 D-\left(1-e_{H}\right)^{2}\left[y^{L}(1-c)-h\left(e_{H}\right)\right]}{e_{H}\left(2-e_{H}\right)}
$$

and

$$
F^{S}=\frac{0.5 D-\left(1-e_{H}\right) y^{L}}{e_{H}} .
$$

Substituting the expression for $\mathrm{F}^{\mathrm{B}}$ and $\mathrm{F}^{\mathrm{S}}$ into $\mathrm{A} 3 \mathrm{~A}$ and simplifying gives: 


$$
y^{L}\left(3-e_{H}\right)-h\left(e_{H}\right)+c\left(1-e_{H}\right)^{2} y^{L}<0.5 D\left(3-e_{H}\right)
$$

which is A3a stated in terms of primitives and consistent with the equilibrium.

Recall A4a: $2 \mathrm{y}^{\mathrm{H}}-\mathrm{h}(\mathrm{e})>\mathrm{y}^{\mathrm{H}}+\mathrm{y}^{\mathrm{L}}-\mathrm{h}(\mathrm{e})>\mathrm{F}^{\mathrm{B}}+\mathrm{F}^{\mathrm{S}}$. Substitute the equilibrium values of $\mathrm{F}^{\mathrm{B}}$ and $\mathrm{F}^{\mathrm{S}}$ into $\mathrm{y}^{\mathrm{H}}+\mathrm{y}^{\mathrm{L}}-\mathrm{h}(\mathrm{e})>\mathrm{F}$, and simplify to obtain:

$$
y^{H} e_{H}\left(2-e_{H}\right)+y^{L}\left(3-3 e_{H}+e_{H}^{2}\right)-h\left(e_{H}\right)-c y^{L}\left(1-e_{H}\right)^{2}>0.5 D\left(3-e_{H}\right)
$$

which is A4a stated in terms of primitives and consistent with the equilibrium. // 
Figure 1: A Two-Tiered Bankruptcy Remote Structure

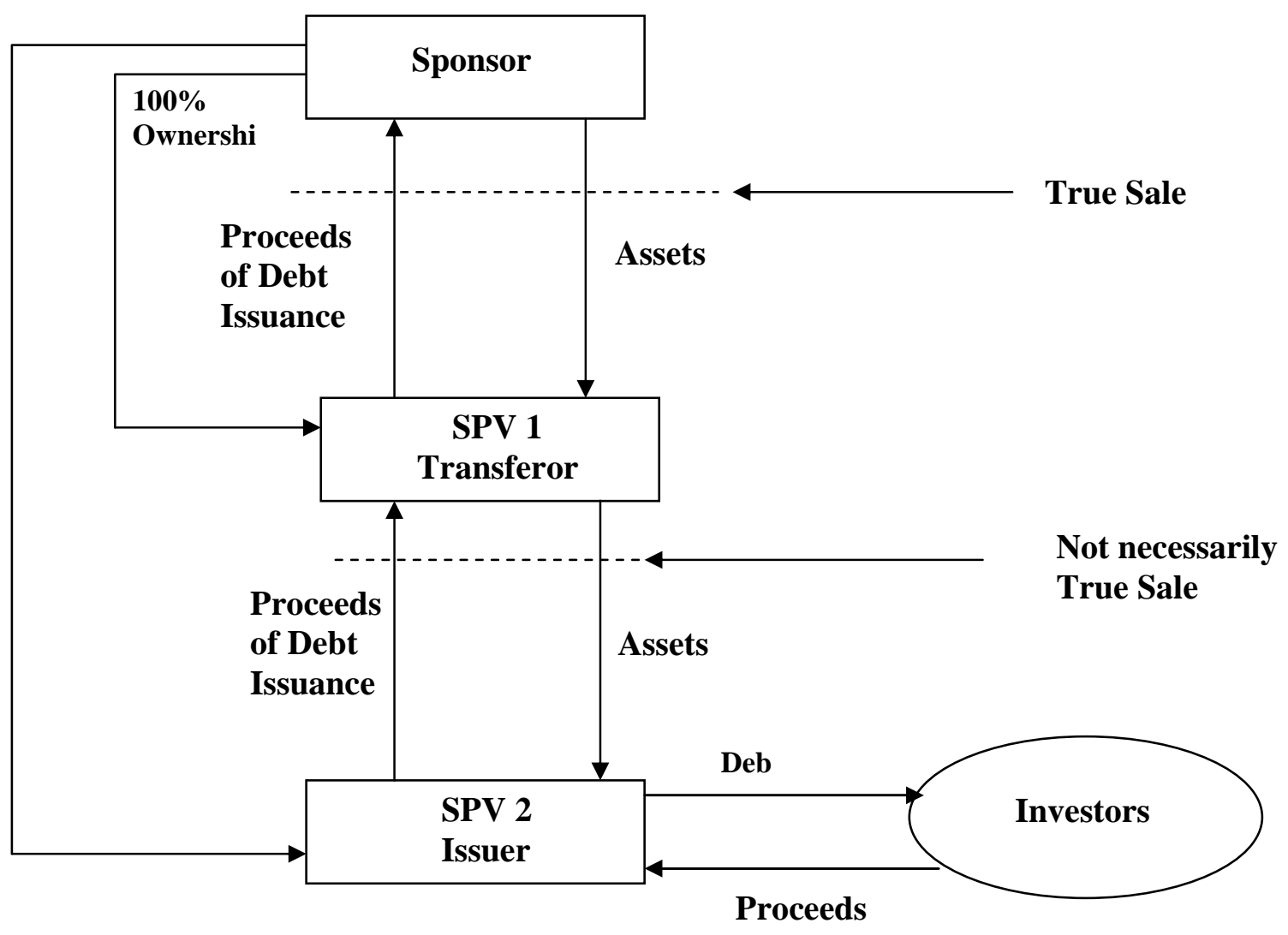

Source: Moody's (August 30, 2002). 
Figure 2: Schematic of a Securitization Transaction

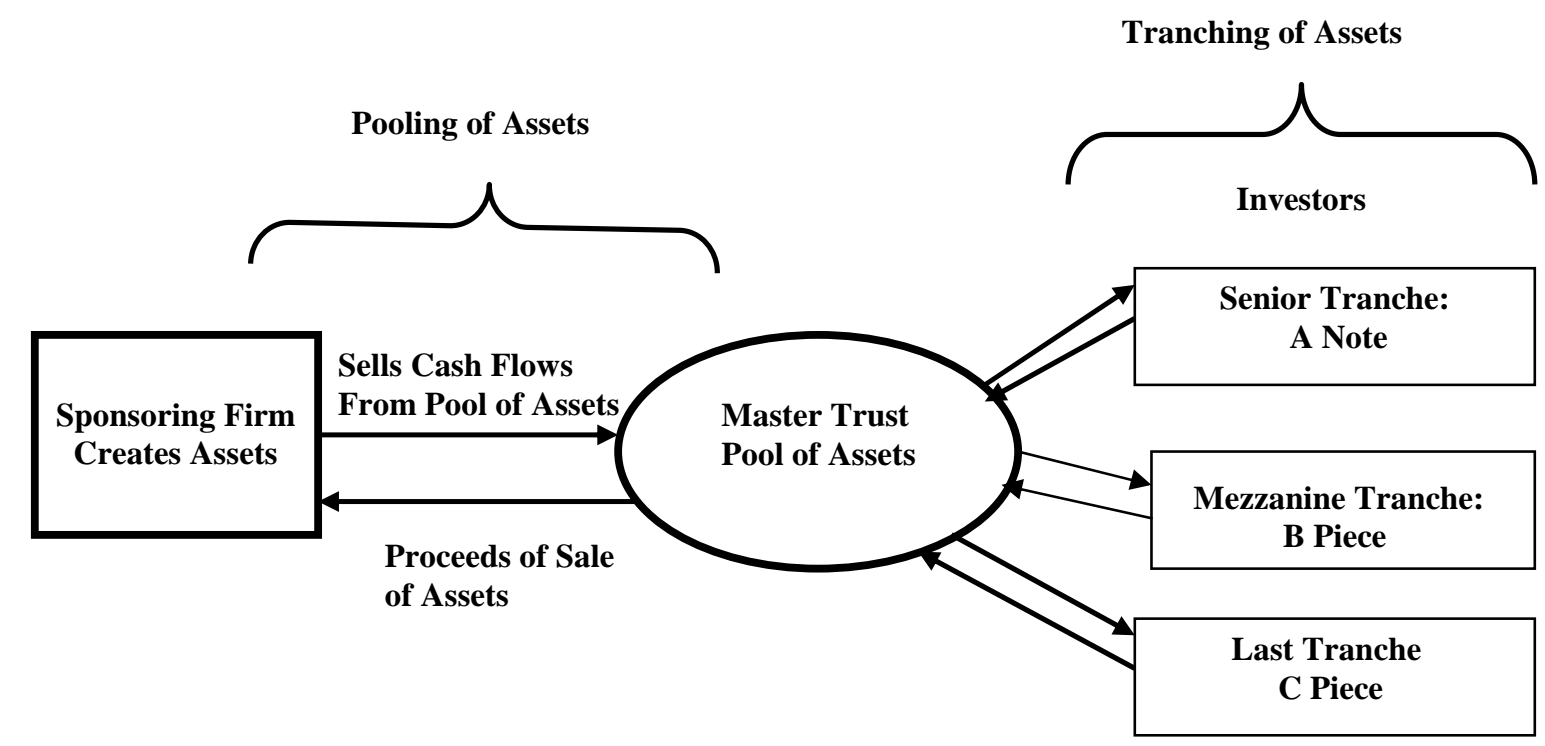


Figure 3

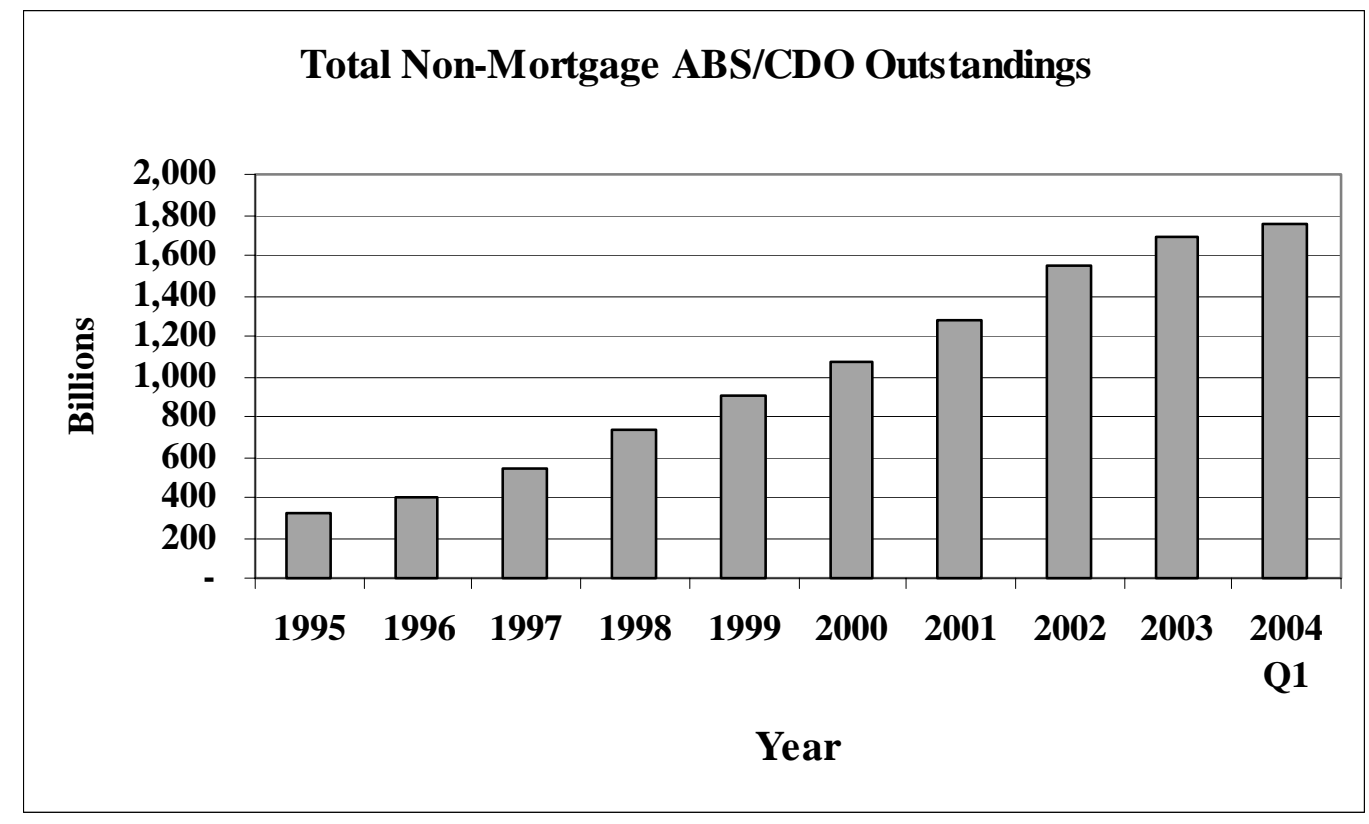

Source: Bond Market Association 
Figure 4: Asset-Backed Commercial Paper Conduits

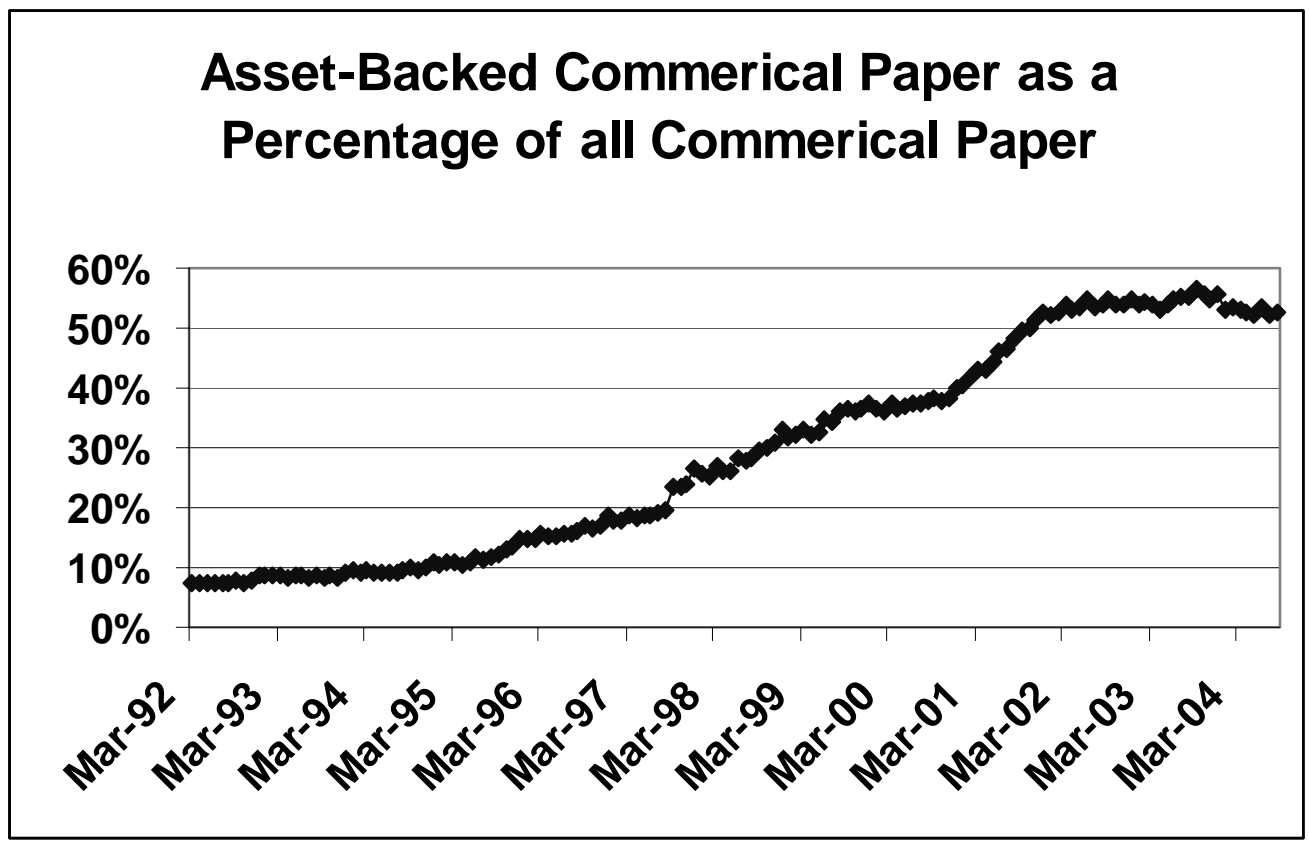

Source: Board of Governors of the Federal Reserve System (http://www.federalreserve.gov/releases/cp/histouts.txt ) 
Table 1: Asset-Backed Securities Outstanding Amounts

\begin{tabular}{|c|r|r|r|r|r|r|r|r|}
\hline & Cars & $\begin{array}{c}\text { Credit } \\
\text { Cards }\end{array}$ & $\begin{array}{c}\text { Home } \\
\text { Equity }\end{array}$ & $\begin{array}{c}\text { Manufactured } \\
\text { Housing }\end{array}$ & $\begin{array}{c}\text { Student } \\
\text { Loans }\end{array}$ & $\begin{array}{c}\text { Equipment } \\
\text { Leases }\end{array}$ & CBO/CDO & Other \\
\hline 1995 & 59.5 & 153.1 & 33.1 & 11.2 & 3.7 & 10.6 & 1.2 & 43.9 \\
\hline 1996 & 71.4 & 180.7 & 51.6 & 14.6 & 10.1 & 23.7 & 1.4 & 50.9 \\
\hline 1997 & 77 & 214.5 & 90.2 & 19.1 & 18.3 & 35.2 & 19 & 62.5 \\
\hline 1998 & 86.9 & 236.7 & 124.2 & 25 & 25 & 41.1 & 47.6 & 144.7 \\
\hline 1999 & 114.1 & 257.9 & 141.9 & 33.8 & 36.4 & 51.4 & 84.6 & 180.7 \\
\hline 2000 & 133.1 & 306.3 & 151.5 & 36.9 & 41.1 & 58.8 & 124.5 & 219.6 \\
\hline 2001 & 187.9 & 361.9 & 185.1 & 42.7 & 60.2 & 70.2 & 167.1 & 206.1 \\
\hline 2002 & 221.7 & 397.9 & 286.5 & 44.5 & 74.4 & 68.3 & 234.5 & 215.4 \\
\hline 2003 & 234.5 & 401.9 & 346 & 44.3 & 99.2 & 70.1 & 250.9 & 246.8 \\
\hline 2004 Q1 & 238.2 & 406.5 & 385.1 & 43.9 & 102.4 & 68.7 & 253.3 & 250.4 \\
\hline
\end{tabular}

Source: Bond Market Association 
Table 2: Sponsor Ratings and Initial Spreads on A Notes: Summary Statistics

\begin{tabular}{lll}
\hline & mean & s.d. \\
\cline { 2 - 3 } Spread & 0.48 & \\
RatingAA & 0.25 & 0.68 \\
RatingA & 0.49 & 0.44 \\
RatingB & 0.26 & 0.50 \\
LowSub & 0.25 & 0.44 \\
Maturity & 5.70 & 0.44 \\
Sellersint & 6.38 & 2.25 \\
FixedRt & 0.35 & 1.21 \\
I_CCA & 0.43 & 0.48 \\
I_LOC & 0.03 & 0.50 \\
I_RES & 0.01 & 0.17 \\
I_Other & 0.02 & 0.08 \\
Seasoned & 0.43 & 0.15 \\
Chargeoff & 5.35 & 0.50 \\
\hline
\end{tabular}

Notes: $\mathrm{N}=167$. The sample is that for $\mathrm{A}$ Notes in Table 3 column (5), averaging over 1988-99. 


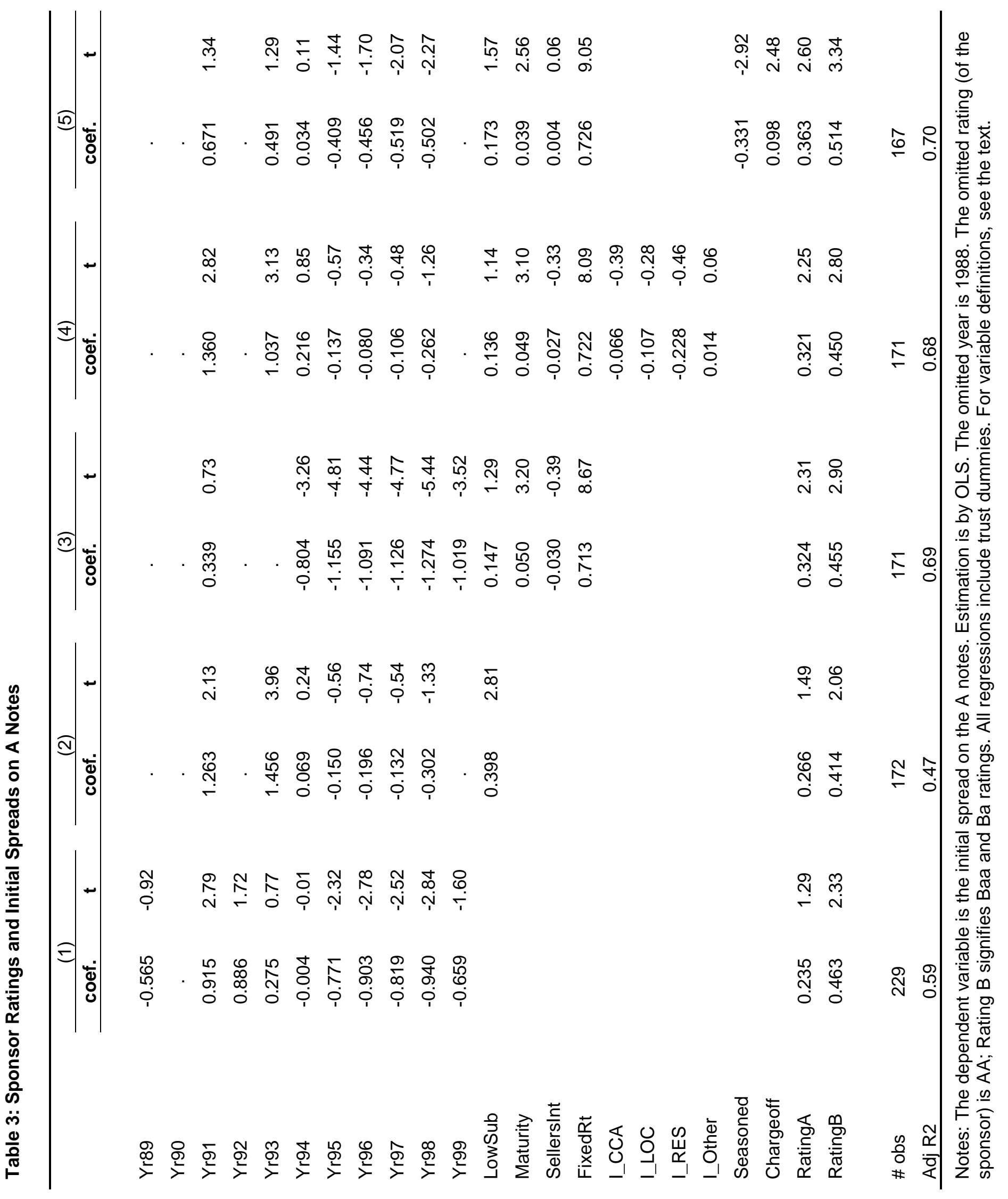




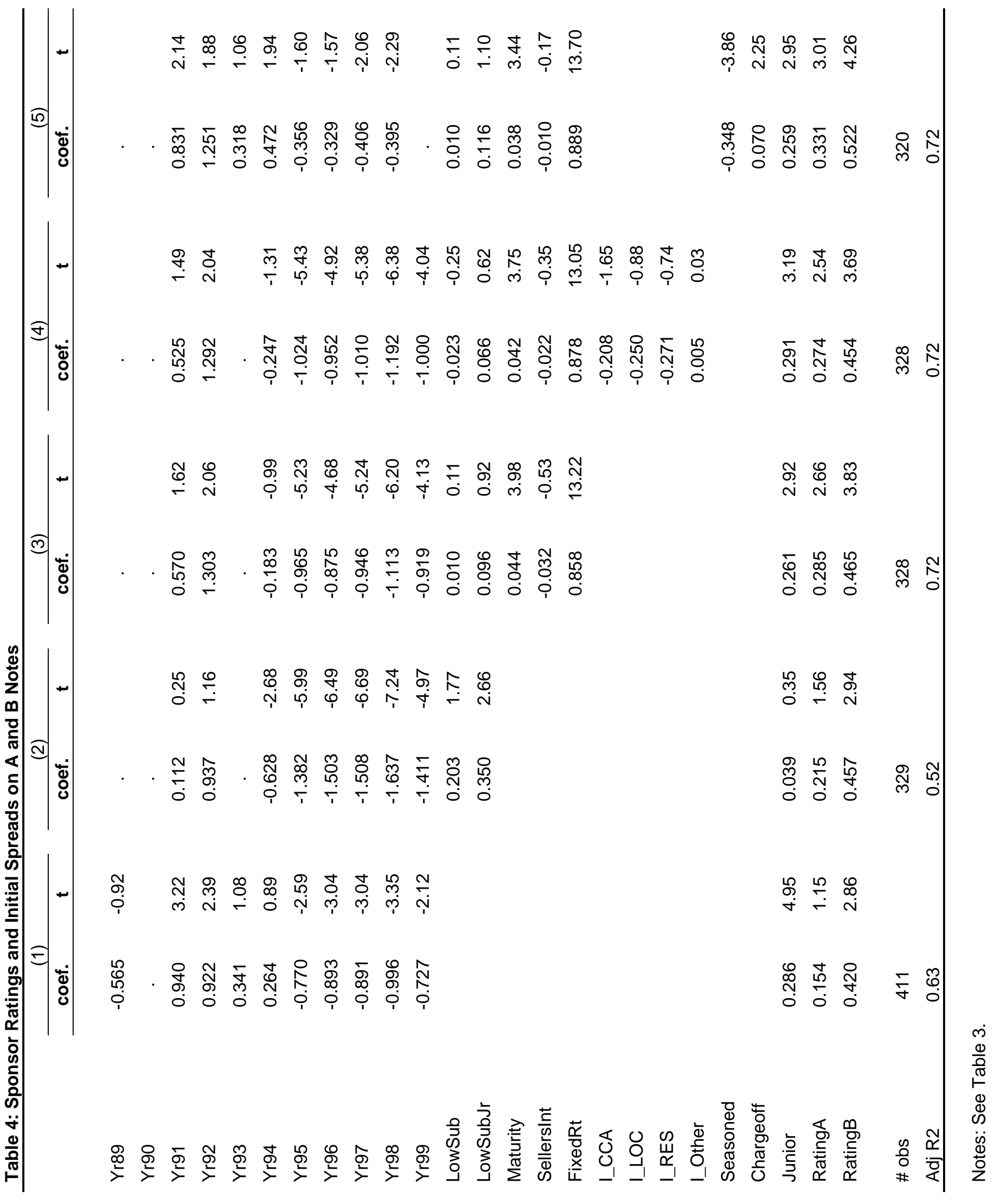


Table 5: Sponsor Ratings and the Propensity to Securitize: Summary Statistics

\begin{tabular}{|c|c|c|c|c|}
\hline & \multicolumn{2}{|c|}{$1991-2000$} & \multicolumn{2}{|c|}{2000} \\
\hline & mean & s.d. & mean & s.d. \\
\hline I_Sec & 0.113 & 0.317 & 0.146 & 0.317 \\
\hline Sec/Assets & 0.033 & 0.124 & 0.041 & 0.124 \\
\hline RatingAA & 0.462 & 0.499 & 0.474 & 0.499 \\
\hline RatingA & 0.446 & 0.497 & 0.397 & 0.497 \\
\hline RatingB & 0.092 & 0.289 & 0.129 & 0.289 \\
\hline Assets (mil \$) & 16.0 & 39.1 & 25.4 & 39.1 \\
\hline CC/Assets & 0.050 & 0.178 & 0.038 & 0.178 \\
\hline CapRatio & 0.086 & 0.036 & 0.086 & 0.034 \\
\hline \# obs & 5012 & & 363 & \\
\hline
\end{tabular}

Notes: In the first panel the sample is that for Table 6 columns (1) and (2), averaging over Call Report Data quarters 1991:09 - 2000:06. The second panel averages over only 2000:03 and 2000:06. See Table 6 and text for variable definitions. 


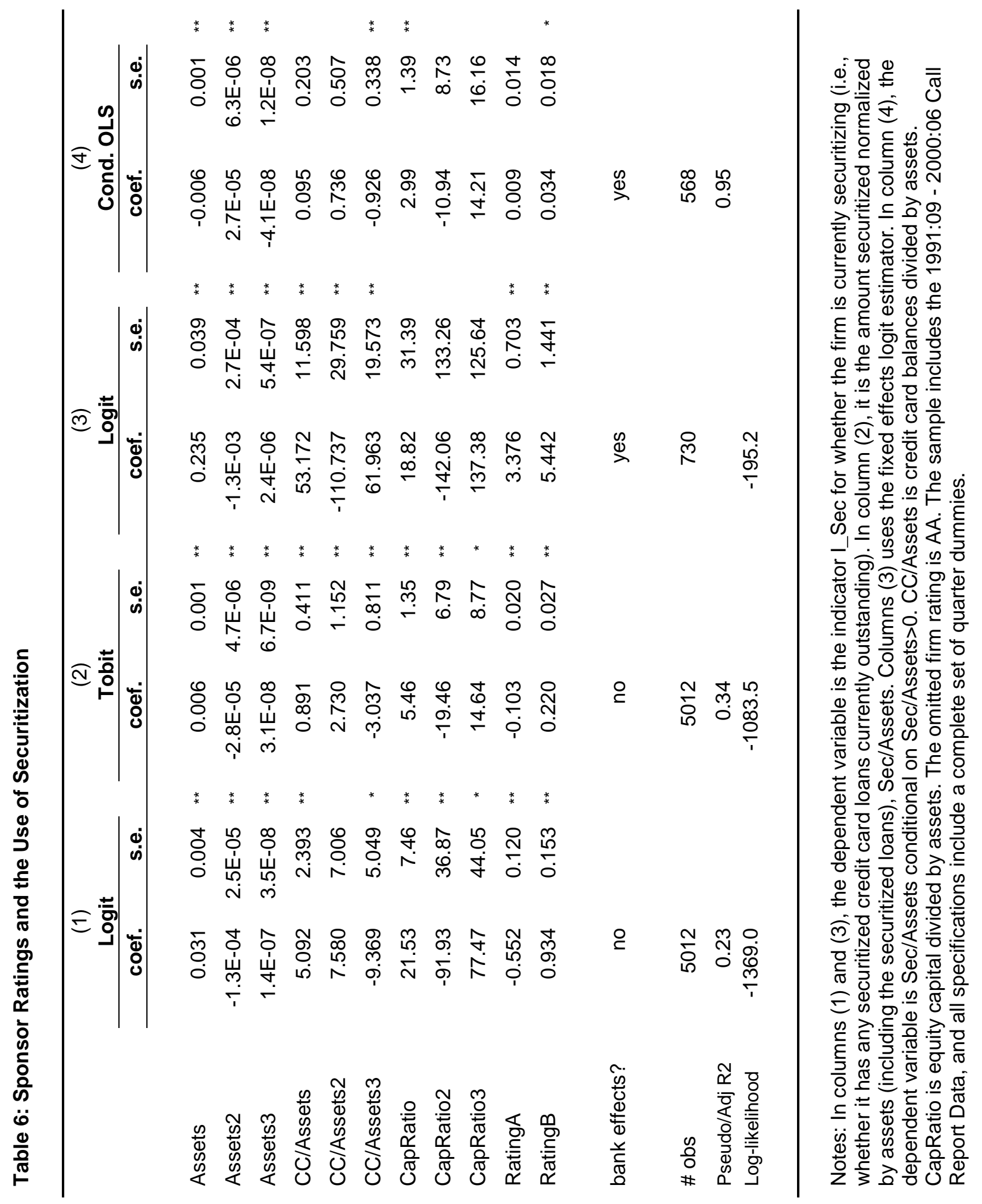

